\section{A PRODUC̣ÃO DA LIBERDADE NO BRASIL ESCRAVISTA (SÉCULO XIX)}

Producing liberty in $19^{\text {th }}$ Century Brazil
Marcelo Santos

\section{MATHEUS ${ }^{*}$}

(D) marcelo.matheus@rolante.ifrs.edu.br

*Instituto Federal do

Rio Grande do Sul

Rolante, RS, Brasil

\section{RESUMO}

Este artigo trata da transição da escravidão para a liberdade no Brasil do século XIX. Ainda que as pesquisas historiográficas recentes tenham sublinhado características sociais dos escravos libertos, este artigo se debruça sobre os "outorgantes" de cartas de alforria. São duas as questões a guiar a análise: por que as cartas de alforria eram tão comuns no Brasil Imperial? Como essa prática se inseria nas relações sociais e conformava a sociedade em geral? Esses problemas são aproximados tomando a cidade de Bagé, na província do Rio Grande do Sul, no extremo sul do Brasil, como locus de análise. Por um lado, o papel relevante das mulheres como proprietárias naquele mundo rural e escravocrata é digno de nota. Por outro, pequenos donos de escravos, que representavam a maioria do grupo, adotaram estratégias específicas na emancipação de cativos, de modo a não perder seu status hierárquico de mestres. Além disso, este trabalho mostra que a produção da liberdade no Brasil Imperial foi um processo complexo que transcende cálculos quantitativos. Entre outros aspectos, enfatizamos a relevância da influência das matrizes culturais ibéricas e africanas para entender a sociedade brasileira do século XIX.

Palavras-chave: Império do Brasil, escravidão, liberdade

\begin{abstract}
This paper focuses on the transition from slavery to freedom in Brazil in the 19th century. Although current historiographical researches highlighted the social characteristics of freed slaves, this work also concentrates on the freedom letters "grantors". Two main questions guided the analysis: why freedom letters were so common in Imperial Brazil? How did this practice intertwine with social relationships and shape society as a whole? To approach these problems, the locus chosen for the analysis was the city of Bagé, in the southernmost province of Rio Grande do Sul. On one hand, the relevant role of women in that slaveholder and rural world is worth of notice. On the other hand, small slave-owners, who represented the majority of their group, adopted specific strategies when emancipating captives, so as not to lose their own hierarchical status of masters. Furthermore, this work shows that the production of freedom in Imperial Brazil was a complex process that must transcend quantitative calculations. Among other aspects, we emphasize the relevance of understanding the influence of Iberian and African cultural matrices to understand the $19^{\text {th }}$ Century Brazilian society.
\end{abstract}

Keywords: Imperial Brazil, slavery, freedom 


\title{
Introdução
}

\begin{abstract}
O escravo pode obrigar o seu senhor a manumiti-lo, desde que lhe ofereça a quantia pelo qual foi comprado, ou o preço pelo qual poderia ser vendido, se este preço for superior ao que valia o escravo na época em que foi comprado.
\end{abstract}

(Henry Koster apud CUNHA, 1986, p. 124).

O claro exagero cometido pelo viajante inglês Henry Koster, destacado na epígrafe, quando afirmou que o senhor era "obrigado" a manumitir seu escravo, como se a alforria ${ }^{1}$ estivesse prescrita na legislação, remete-nos a algo deveras interessante: a passagem da escravidão para liberdade foi algo tão corriqueiro no Brasil, tanto antes da Independência quanto no Período Imperial, que alguns contemporâneos entendiam que esse fenômeno estivesse inscrito na legislação da época. Contudo, como bem apontou Manuela da Cunha, a concessão da liberdade via alforria era um costume, não existindo uma lei específica que a regulasse. Conforme a autora, conceder a manumissão era uma prerrogativa que competia "exclusivamente ao senhor" (CUNHA, 1986, p. 126). Isso pelo menos até 1871, ano da promulgação da Lei do Ventre Livre, que tornou oficial o direito à manumissão ao escravo que conseguisse juntar o valor necessário para a compra da sua liberdade, embora o direito a este pecúlio ainda dependesse da anuência do senhor.

Essa prerrogativa senhorial torna ainda mais interessante a análise deste processo, já que a conquista da liberdade mediante a carta de alforria foi uma tônica na história brasileira. Conforme Robert Slenes, no século XIX, "as taxas de alforria no Brasil [...] eram suficientemente altas para que todo o cativo pudesse sonhar com a liberdade como uma possibilidade real" (SLENES, 1999, p.200). Na verdade, esse fenômeno foi tão abrangente, que Manolo Florentino elaborou o que seria uma "cultura da manumissão", em que outro "direito" senhorial - a possibilidade de revogar a liberdade (pelos menos até 1871) praticamente não precisou ser acionado, vicejando um "padrão cultural" em que elementos outros, que não a regulação por parte do Estado (diferentemente dos diversos códigos existentes em muitos estados dos Estados Unidos, que proibiam ou ao menos colocavam interdições à alforria), é que ditavam a dinâmica da relação entre escravos e senhores (FLORENTINO, 2010, p.87; CHALHOUB, 2010, pp. 35-36).

É sob esse entendimento (de uma "cultura da manumissão") que se torna possível compreender a normalidade do caso de Venturosa de Oliveira, escrava que residia em Bagé. Venturosa era escrava de Felisbina Francisca de Oliveira e, em meados da década de 1860, desejava se libertar. Com consentimento de sua senhora, Venturosa organizou entre o final do ano de 1864 e o início de 1865 uma "ação entre amigos". As informações em relação à "ação" eram publicadas no jornal 'O Bageense', que informava aos apostadores sobre o andamento da "loteria" que tinha como objetivo "a liberdade da escrava Venturosa de Oliveira"2.

Não à toa, talvez esse processo - a passagem da escravidão para liberdade de maneira institucional, isto é, via manumissão - seja um dos aspectos mais bem estudados do passado escravista brasileiro. Nesse contexto historiográfico, esse artigo tem como objetivo analisar as características daqueles indivíduos que foram alforriados em uma realidade 
específica. Entretanto, ao contrário de boa parte das pesquisas que privilegiam apenas os manumitidos, iremos abordar também as características daqueles que alforriaram. Não obstante, análises de cunho qualitativo foram realizadas com o intento de enriquecer o debate geral aqui realizado. Nesse ínterim, destacamos a questão da família escrava, e suas implicações não só para a produção da liberdade, como também para as relações escravistas de maneira geral.

Para tanto, o recorte espacial que serviu para aplicação das questões postas foi o município de Bagé, na província do Rio Grande do Sul (doravante RS), extremo sul do Império do Brasil, antes da promulgação da Lei do Ventre Livre - uma localidade rural, cuja economia estava assentada na agropecuária, com uma população estimada em 15 mil pessoas (por volta de 1/3 deles de escravos, em sua maioria - 70\% - de crioulos), e onde a posse cativa estava disseminada, predominando as pequenas escravarias (MATHEUS, 2016, cap. 2 e 4$)^{3}$. Por tudo isso, é uma localidade bastante representativa do Brasil oitocentista.

Contudo, antes de passarmos para as mencionadas análises, três procedimentos foram realizados. Junto com a apreciação dos alforriados, abordarmos as características gerais das alforrias (a sua frequência ao longo do tempo, bem como a tipologia das mesmas). Antes ainda, duas abordagens são importantes: primeiro, aventamos sobre o porquê de a concessão de alforrias no Brasil ter sido algo tão ordinário; depois, vamos nos valer de um debate realizado em outra oportunidade, para assimilarmos os diferentes entendimentos produzidos acerca do significado que a produção de liberdades tinha, e da função que esse processo exercia na dinâmica das relações escravistas (MATHEUS, 2012, pp. 28-42).

\section{A pawnship, a cultura ibérica e o costume das alforrias}

É possivel afirmar que a prática da alforria (ou a "cultura da manumissão", como postula Manolo Florentino) era algo corriqueiro enquanto a escravidão vicejou no Brasil. Partindo desse pressuposto, indaga-se: qual a natureza da impressionante dimensão da prática da alforria no Brasil colonial e imperial?

Na sua obra clássica Slave and Citizen, Frank Tannenbaum destaca a diferença entre o status que escravos e libertos adquiriram na América inglesa (nos Estados Unidos, particularmente) e na América ibérica. De acordo com Tannenbaum, na região colonizada por portugueses e espanhóis, os escravos eram entendidos como seres dotados de uma "personalidade moral" e, portanto, portadores de alma. Por sua vez, na região colonizada pelos ingleses, a "doutrina" negou aos cativos a "moral pessoal". Como corolário desses diferentes sistemas valorativos, na primeira os escravos foram entendidos como seres capazes de viver em liberdade e, por isso, as taxas de alforria foram altas, sem que as leis civis estipulassem maiores restrições aos libertos. Já na segunda região ocorreu exatamente o contrário: baixo percentual de manumissões e a elaboração de um arcabouço jurídico que restringia a autonomia dos forros e seus descendentes, criando-se sociedades estratificadas, que tinham como elemento-chave dessa estratificação a "raça"/cor da pele (TANNENBAUM, 1947, pp.xviii-ix) ${ }^{4}$.

A origem da diferença na natureza dos dois sistemas escravistas estaria nas raízes das legislações ibérica e inglesa. No primeiro caso, segundo Frank Tannenbaum, a grande 
influência do Direito Romano, especialmente do Código de Justiniano, teve um papel central. Conforme essa tradição, a escravidão afeta apenas o corpo do indivíduo (com sua alma permanecendo livre) e, por isso, o escravo sofre as mesmas dores e alegrias dos outros seres humanos, pois "deriva da mesma fonte". Enfim, tanto escravos como senhores seriam iguais perante Deus ("Deus não fez escravos e homens livres, mas sim todos os homens livres"), o que, se não deslegitimava a escravidão, a colocava em outros termos. É a partir dessa perspectiva que Alfonso, rei de Castela e Leão, publicou Las Siete Partidas, no século XIII, garantindo à escravidão um "corpo de leis" em que o escravo era considerado "um ser humano" (TANNENBAUM, 1947, pp.45-48)

É fundamental ressaltar que esse pensamento foi elaborado muito antes de a escravidão ser relacionada com os negros escravizados e traficados da África, algo que irá acontecer apenas no final do século XVIII, estendendo-se até o século XIX. Entretanto, conforme Frank Tannenbaum, os cativos negros foram incluídos e, por consequência, beneficiaramse desse corpo de leis (que foi transportado para a América), condicionando sobremaneira a posição dos escravos na sociedade. Para o autor, foi essa tradição jurídica, muito influenciada pela doutrina cristã, que na América ibérica "abriu as portas para a alforria" através do incentivo aos senhores para que alforriassem seus cativos, e para que estes que buscassem a liberdade, mesmo sem interferir no "espaço doméstico" (i.e., mesmo sem interferir diretamente no poder senhorial) ${ }^{6}$.

Atuando para que a alforria fosse algo disseminado no escravismo brasileiro, ao lado do costume herdado da tradição e da legislação ibérica estava a cultura africana, em que a escravidão, embora a partir de uma natureza diversa, era conhecida, assim como outras formas de servidão. Uma delas foi o que Mary Douglas, estudando a África Central, notadamente de onde mais vieram africanos para o Brasil, denominou de "pawnship" (DOUGLAS, 1964, p. 301)7. Mas o que era a pawnship e por que ela poderia estar ligada ao costume da alforria (isto é, à prática de uma escravidão/servidão que tinha no seu horizonte muitas vezes a transitoriedade)?

Primeiro, e mais importante, é preciso dizer que a pawnship não é o mesmo que a escravidão, até porque ambas as instituições coexistiram em diferentes regiões da África Atlântica (Central e Ocidental) ${ }^{8}$. O pawn (espécie de servo por dívida) não pertencia ao detentor dos direitos sobre seu trabalho, isto é, não poderia ser vendido, embora seu trabalho pudesse ser passado para outrem exercer poder/controle sobre o pawn.

Por sua vez, como observam Paul Lovejoy e Toyin Falola, "pawns poderiam acabar como escravos, e, às vezes, os escravos poderiam se tornar um pawn". Da mesma forma, o credor, assim como o senhor de um escravo, também era responsável pela subsistência (alimentação, vestimenta e local para residir) do pawn, o que faz com que Lovejoy e Falola percebam, assim como na escravidão, a existência de um certo grau de paternalismo nessa relação. Portanto, a pawnship era uma espécie de servidão voluntária, mas sobretudo transitória (caso a dívida fosse paga), que sobreviveu, inclusive, até o século XX (LOVEJOY e FALOLA, 2003, pp. 4, 12 e 20-24) ${ }^{9}$.

Contudo, a nosso ver, é a coadunação, na sociedade colonial, da tradição da alforria (inscrita na legislação ibérica através das Siete Partidas) com o costume da pawnship, especialmente pelo seu caráter de servidão transitória, que em parte talvez ajude a explicar 
a impressionante dimensão e vitalidade das manumissões ao longo da história brasileira. Nesse sentido, os africanos traficados para o Brasil - mesmo porque "um certo número de africanos escravizados que foram vítimas do comércio transatlântico eram originalmente pawns", fenômeno que, conforme Roquinaldo Ferreira, cresceu com o aumento da demanda por escravos nas Américas (FERREIRA, 2012, cap. 3) 10 $^{10}$ tinham na sua estrutura mental a noção de que a escravidão poderia ser também transitória, já que vigorava o costume de, através do trabalho e dos bons serviços, concessão/conquista de alforrias.

Isso talvez seja tão ou mais verdade para um contexto em que boa parte dos escravos eram crioulos, como a realidade aqui estudada. Ao contrário de sociedades em que os cativos (como, por exemplo, os africanos) eram indivíduos externos a ela, ou "outsiders" nas palavras de Paul Lovejoy e Toyin Falola, os escravos crioulos nasciam já familiarizados com o sistema escravista, de maneira mais ampla, e com a família senhorial, particularmente. Conforme Lovejoy e Falola, esse era o mesmo contexto dos pawns, os quais podiam ser assimilados pela família daqueles que detinham o direito sobre seu trabalho, caso estivessem ligados à servidão por muito tempo. Por isso, geralmente, "escravos poderiam servir" como pawns "somente se eles fossem aculturados e, portanto, membros da sociedade". Da mesma maneira, era algo comum parentes "resgatarem" os seus, tanto da escravidão quanto da pawnship (LOVEJOY e FALOLA, 2003, p. 5; MILLER, 1978, pp. 52-53).

Essa herança de costumes, ou mesmo instituições africanas, não deve ser menosprezada. E não só pelo fato de cerca de 1/3 dos escravos em Bagé até 1870 serem de africanos - ou mesmo pela obviedade de que os crioulos eram descendentes de africanos.

Com efeito, o primeiro cura da Capela de São Sebastião de Bagé em 1818, Gervásio Antônio Pereira Carneiro, foi "catequizador" entre 1796 e 1800; depois, novamente em 1810, foi "inquiridor das liberdades" (i.e., funcionário da coroa portuguesa) em Benguela. Sua função, para além das obrigações eclesiásticas, era exatamente a de não permitir que escravizações ilegais fossem realizadas. Ou, em outras palavras, não permitir que a pawnship fosse utilizada para escravizar africanos súditos do rei, que seriam embarcados ilegalmente em navios com destino ao Brasil. Para tanto, o governador de Benguela indicava um padre que, em geral, dominava a língua nativa para que servisse de tradutor para africanos que alegavam ser livres, e não escravos, na hora do batismo e do embarque (FERREIRA, 2012, pp. 107-108)11. Enfim, como postulam Paul Lovejoy e David Richardson, "a presença de pawns em populações escravizadas" nas regiões africanas tocadas pelo tráfico atlântico de escravos "fornece provas" suficientes que "ajudam a explicar como a África interagiu com" a cultura atlântica de maneira mais ampla (LOVEJOY e RICHARDSON, 2003, p. 28).

\section{O(s) significado(s) da produção de liberdades}

No geral, poderíamos separar alguns dos principais autores que abordam a cultura da manumissão em duas correntes interpretativas: aqueles que entendem a alforria como uma concessão senhorial, e por isso servia para reproduzir o sistema social vigente; e aqueles que a consideram como uma conquista frente à vontade senhorial - conquista que, no longo prazo, serviria para desgastar as bases do sistema escravista.

Silvia Lara, por exemplo, compreende que "os cativos se aproveitaram de brechas na própria dominação senhorial, abertas pelas tensões existentes" na dinâmica das relações 
escravistas, aproveitando-se para "obter alforrias, liberdades, doações, etc.". Para a autora, a manumissão e outras conquistas dos cativos não eram somente concessões senhoriais: representavam também "inegavelmente" "formas de resistência" ao sistema, o que de resto moldava o cativeiro e impunha limites ao poder senhorial (LARA, 1988, p. 345).

Ainda conforme Silvia Lara, "a 'generosidade' senhorial [no ato de conceder a manumissão] não conseguira produzir seres agradecidos e submissos", com "as alforrias" produzindo "um contingente de homens e mulheres altivos e presunçosos", fenômeno "que se tornava uma questão política". De acordo com a autora, essa "presença massiva de homens negros e mulatos libertos apresentava, sem dúvida, um potencial político eminentemente disruptivo", postulando desse modo que o resultado da alforria (a produção de "homens negros e mulatos libertos") ameaçava a ordem escravista, pois "evidenciava as dificuldades do domínio senhorial" (LARA, 2007, pp. 277-279).

Sob a mesma concepção teórica, mas a partir de uma visão que leva em conta tanto o ponto de vista senhorial quanto o dos escravos, Sidney Chalhoub argumenta que a produção de uma liberdade deve ser compreendida "como o resultado dos esforços bemsucedidos" de um cativo "de arrancar a liberdade de seu senhor". O que para o senhor era uma "concessão ou doação" deve ser interpretado como uma "conquista" do ponto de vista do escravo (CHALHOUB, 1990, p. 23) ${ }^{12}$.

Por outro lado, Roberto Guedes considera a alforria "basicamente, uma concessão senhorial". Segundo Guedes, "com certeza" as manumissões foram estimuladas "pela pressão dos escravos, mas não se trata de resistência dentro do sistema. No limite, é um acordo desigual, em que uma parte dá e outra aceita. É concessão, predominantemente". Portanto, ao escravo, "aceitar uma concessão de forma submissa é um primeiro passo de reinserção social pela via legal" (GUEDES, 2007, pp. 87-88).

A partir do mesmo arcabouço interpretativo, Márcio Soares também postula que a alforria era sempre uma concessão. Para o autor, "do ponto de vista senhorial, a eficácia da manumissão residia na possibilidade de a mesma sempre ser representada como uma dádiva [...], inclusive as pagas". Soares entende a dádiva como uma relação de reciprocidade, em que o liberto ficava obrigado a retribuir ao seu ex-senhor a concessão, ou melhor, a "Dádiva da Alforria", título de sua obra. Por isso, "se por um lado [...] a alforria significava a interrupção do cativeiro, por outro ela era um elemento chave, intrínseco ao processo que instituía a própria escravidão". Resumindo, Márcio Soares defende que "a concessão das alforrias e seus desdobramentos reforçavam politicamente a escravidão" (SOARES, 2009, pp. 22 e 273-276).

Por sua vez, Manolo Florentino salienta que a alforria tinha um caráter conservador, pois era um meio instituído socialmente para se chegar à liberdade, não operando para a transformação da sociedade (FLORENTINO, 2005, pp.333-334). Como existia, até 1871, - "estatuto jurídico da re-escravização", na prática muitas alforrias funcionavam como "mecanismos de contínua produção de patronagem" (FLORENTINO, 2010, p.90). Todavia, Florentino avança sobre a dualidade concessão/conquista, argumentando que, mesmo que "toda e qualquer manumissão" seja uma "concessão senhorial", é salutar observar a importância da ação do cativo enquanto ator social, especialmente nas alforrias pagas, já que 
uma carta comprada era importante pelo que significava e ensejava para o liberto, tanto demográfico e politicamente quanto, em última instância, do ponto de vista da afirmação de sua identidade. A carta comprada [...] configurava o resultado último da ação de redes de relações sociais que envolviam os escravos entre si, a família cativa, escravos e senhores, forros, homens livres pobres [...] (FLORENTINO, 2010, pp. 97-100).

Hebe Mattos introduz um aspecto relevante ao debate sobre as consequências da significativa produção de liberdades no Brasil. A autora argumenta que a manumissão tinha um papel central na política de dominação senhorial, sendo o principal recurso moral dos proprietários. Entretanto, segundo ela, a possibilidade da alforria engendrava a diferenciação social no cativeiro, antes de aproximar escravos e ex-escravos em uma luta comum (MATTOS, 1995, p. 183).

Nesse contexto, como mencionado anteriormente, a apreciação que fizemos das alforrias segue a mesma linha teórica do realizado em trabalho anterior (MATHEUS, 2016, cap. 6). Cremos que tentar encaixar os diferentes processos pelos quais liberdades foram produzidas reduz a riqueza, a complexidade e a possibilidade de análise que cada alforria registrada pode nos revelar ${ }^{13}$ - o que não quer dizer que o recurso analítico da quantificação (por nós utilizado) não seja importante. Claramente, a alforria era o passo mais importante na trajetória de ascensão social de um escravo, pois significava a passagem da escravidão para o mundo dos livres. Não com todas as prerrogativas, pois um liberto não poderia participar da segunda fase das eleições, isto é, ser votado (um liberto africano, caso não se nacionalizasse, nem isso), embora pudesse participar da primeira fase da mesma (ser votante). Mas, enfim, tornava-se uma pessoa livre.

Porém, o postulado é que a alforria era uma possibilidade e um objetivo dentre tantos outros que os cativos vislumbravam para suas vidas (possivelmente o mais desejado e o mais difícil). Assim, antes da liberdade, o indivíduo podia ter como projeto de vida, por exemplo, a melhora da sua alimentação, a possibilidade de ter maior liberdade de movimentação para visitar parentes e amigos em outra propriedade, o acesso a um pedaço de terra para cultivo próprio ou a um pequeno rebanho, mais tempo para trabalhar para si, a possibilidade de casar ou mesmo de manter laços de reciprocidade (embora entre desiguais) com a família senhorial.

O quanto essa busca por melhor viver minava o sistema escravista ou, do contrário, legitimava o status quo? O defendido é que muitas vezes a liberdade não significava uma coisa, nem outra - o que não é o mesmo que dizer que significava ambos os postulados.

Nesse panorama, essa liberdade almejada, e muitas vezes conquistada, era "precária", como observou Sidney Chalhoub (CHALHOUB, 2010)? Provavelmente sim - e pelas razões corretamente elencadas pelo autor ( limitação no que diz respeito à participação política, limitação ao acesso à educação, constante vigilância da polícia sobre "livres de cor" e, mais importante para o que estamos analisando, incerteza dos libertos condicionais e da possibilidade da revogação - embora, como já mencionado, praticamente não tivesse sido acionada - da alforria, além das práticas ilegais de [re]escravização de pardos e de negros livres) -, ainda mais aos olhos do historiador ou do mero espectador do final do século XX 
e início do século XXI. Contudo, cremos que os próprios escravos e libertos que viveram aquele contexto tinham a consciência e a noção de tal questão, ou de tal precariedade, e mesmo assim em muitos casos lutavam pela sua liberdade e a dos seus.

Por seu turno, não há como negar que a alforria era uma concessão senhorial. Logo, concedia-se àqueles e àquelas mais bem situados dentro da hierarquia da escravidão (i.e., aqueles/aquelas com mais recursos, simbólicos e materiais, para inclusive pressionar pela liberdade), ou àqueles e àquelas com uma maior proximidade com a família senhorial elementos que, amiúde, se coadunavam na mesma pessoa/grupo. E, cremos, o elemento central para melhor situar-se naquela sociedade era a família - ou, em outras palavras, estar imerso em sólidos laços parentais. Retomaremos esse aspecto mais à frente.

Dito isso, sigamos para conhecer com que intensidade e com que características o fenômeno da manumissão se reproduziu na localidade (Bagé). Neste intento, abordamos quem eram os escravos que conseguiram recursos (de novo, simbólicos e materiais) para transpor a barreira entre a escravidão e a liberdade, assim como quem eram os senhores que alforriaram naquele contexto.

Antes, é importante esclarecer que nesse artigo tratamos essencialmente das liberdades registradas em cartórios (as cartas de alforria). A escolha se deve ao fato de que um número incerto de manumissões passadas em verbas testamentárias podem não ter se confirmado (por exemplo, em razão de o cativo morrer antes do senhor, já que praticamente todas elas eram concedidas com a condição do escravo permanecer no cativeiro até o falecimento do senhor ou mesmo do casal de proprietários, isto é, até a abertura do testamento), enquanto que as cartoriais, ao menos as gratuitas e pagas, com certeza se efetivaram inclusive algumas testamentárias (assim como outras concedidas na pia batismal) foram depois confirmadas frente a um tabelião. Devido às enormes distâncias que separavam os cartórios das localidades onde os escravos viviam, o próprio liberto muitas vezes levava a carta de alforria para ser registrada, ato que provavelmente tinha uma significativa carga simbólica para o mesmo ${ }^{14}$.

Por fim, importante esclarecer que infelizmente os livros de notas do município de Piratini, ao qual Bagé pertencia até 1846, foram extraviados. Portanto, as alforrias analisadas começam apenas em 1847, estendendo-se até 1870.

\section{Os escravos alforriados}

Embora fosse um fato corriqueiro em todas as regiões do Brasil oitocentista, a concessão de alforrias atendeu a dinâmicas outras, que diziam respeito às especificidades (padrão demográfico, se meio urbano ou rural, economia, etc.) de cada localidade, o que fez com que a frequência de manumissões mudasse de uma região/local para outra(o) ao longo do tempo. Nesse contexto, é fundamental dizer que na fronteira sul do Império, em especial na região da Campanha, onde se situava o município de Bagé, o registro de alforrias em cartório apresentou uma trajetória crescente durante todo o século XIX.

Não é nossa intenção abordar por que a concessão de alforrias cresceu significativamente na Campanha sul-rio-grandense após 1850 e, principalmente, depois de 1871, pois já o fizemos em outra oportunidade (MATHEUS, 2012, cap.3 e 5) ${ }^{15}$. De resto, cumpre apenas 
apontar que o contexto fronteiriço potencializou, de maneira bastante peculiar, o processo de perda da legitimidade da escravidão, que se agravava no final dos anos 1860 na esteira da Guerra do Paraguai, do desdobramento da Guerra Civil nos Estados Unidos, e dos debates que se acirravam no Conselho de Estado sobre o que fazer com o elemento servil (MATHEUS, 2012, pp. 259-265) ${ }^{16}$. Dito isso, passamos a conhecer as características daqueles que foram manumitidos e daqueles que os alforriaram na localidade.

Entre 1847 e 1870, foram registradas 350 cartas de alforrias nos cartórios de Bagé, as quais contêm 367 liberdades, pois em algumas delas mais de um escravo foi manumitido. É fundamental apontar que esse é um número mínimo de liberdades, já que, entre 1829 e 1870, 78 batizandos foram alforriados na pia (com algumas destas manumissões sendo registradas em cartórios), além de pouco mais de 100 alforrias concedidas em verbas testamentárias (da mesma forma, algumas também foram registradas em cartório após a morte do senhor), fora aquelas liberdades passadas de maneira informal, isto é, acordadas apenas entre o senhor e seu cativo (MATHEUS, 2016, cap.6).

Aquelas 350 cartas de alforria correspondem a uma média de 14.5 manumissões (ou 15.5 liberdades) por ano. No 'Gráfico 1', abaixo, é possível observar a frequência desse processo a cada cinco anos - menos o primeiro recorte, pois os registros começam somente no ano de 1847.

Gráfico 1: Frequência das alforrias por sub-recortes (Bagé, 1847-1870)

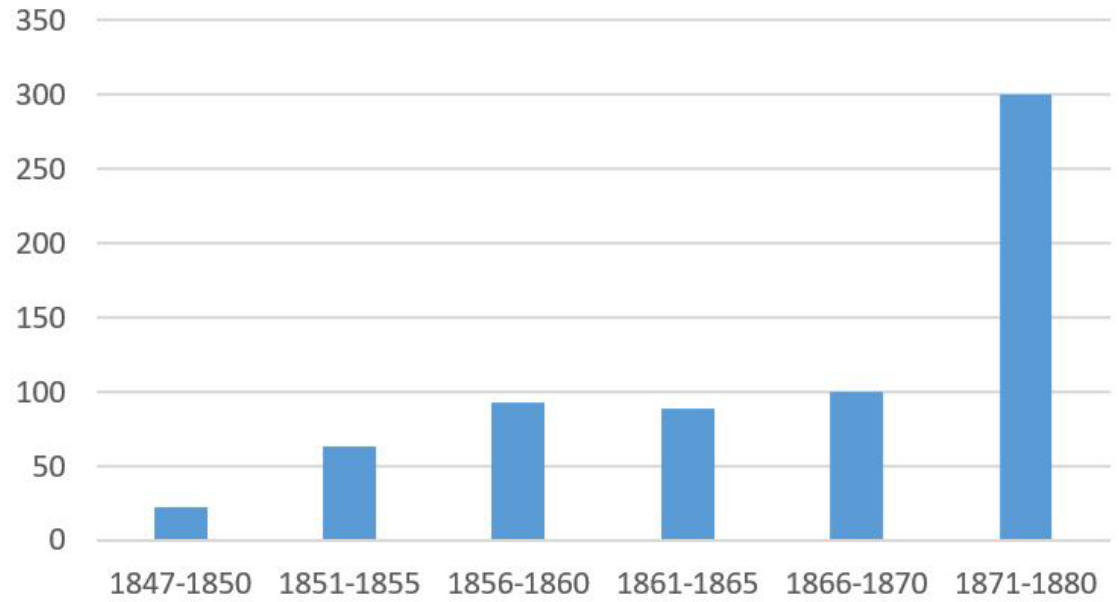

Fonte: APERS. Livros Notariais de Transmissão e Notas e LNRD, Bagé, 1847-1870.

O que era uma tendência ao longo dos anos, na década de 1870 explode, com o número de manumissões chegando a cerca de 30 por ano, ou o dobro dos decênios anteriores. Na verdade, um crescimento constante pode ser observado a partir de 1850, quando do final do tráfico - embora em alguns anos específicos, como 1856 e 1858, tenha havido uma leve 
queda. Mas é a partir de meados da década seguinte que há um crescimento substancial, que continuará na década de 1870 (quando foram registradas cerca de 300 alforrias, ou quase o mesmo número que nas duas décadas anteriores), após a aprovação da Lei do Ventre Livre, em 1871.

Dividindo a média de manumissões por quinquênios, temos que entre 1847-1850 foram registradas 4.5 alforrias, passando para 12.6 entre 1851-1855, 18.6 entre 1856-1860, com uma leve recaída entre 1861-1865 (17.8), para subir novamente entre 1866-1870 (20). No geral, entre 1851-1870, a média foi de 17.25 manumissões por ano.

Para termos uma noção do que isso significa, em Alegrete, município vizinho a Bagé e com características econômicas e demográficas muito parecidas, entre 1851-1871 a média de alforrias foi de 7.8 ao ano. Por seu turno, em Rio Grande, município portuário da província do RS, a média de alforrias praticamente se manteve estável (em cerca de 20 manumissões a cada cinco anos) entre 1845 e 1865, tendo ocorrido uma brutal queda apenas entre 1856-1860, com 7.4 alforrias, para se recuperar no último quinquênio, 18611865 (24). Já conforme Enidelce Bertin, em São Paulo, entre 1850 e 1871 a média foi de 11.6 alforrias concedidas; e, em Campinas, a média foi de 6.9, mantendo-se estável nos anos 1850 (6.1), passando para 13.7 na década de 1860. Por sua vez, em Juiz de Fora as alforrias saltaram de 2.5 entre 1844-1850 para 11.7 entre 1851-1860, e para 17.6 no decênio seguinte. Conforme Heloísa Teixeira, em Mariana, província de Minas Gerais, a média de manumissões oscilaram de 10.8 na década de 1840 para 17.7 na década seguinte, e 10.5 nos anos 1860. Já em Rio das Contas, província da Bahia, a média de alforrias registradas entre 1850-1871 foi de 17.4 (SCHERER, 2008, pp. 67-68; BERTIN, 2004, pp. 69-70; ZERO, 2009, p. 95; LACERDA, 2005, p. 51; TEIXEIRA, 2012, p. 7; ALMEIDA, 2006, p. 125).

Portanto, fica claro que, na região da Campanha, as possibilidades de ascender socialmente atravessando a fronteira entre a escravidão e a liberdade era uma realidade que não se distanciava muito de outras regiões (tivessem elas características próximas, ou não, às da localidade aqui estudada); isto é, as chances de um escravo conquistar a alforria não era, em absoluto, muito menor que em várias localidades do Brasil Imperial. Nesse sentido, quais eram as características dessas manumissões? Mais: quais eram as características daqueles cativos alforriados?

Ao longo do período, 36\% das liberdades foram gratuitas, ou seja, em tese, sem nenhuma exigência ou contrapartida; 31\% delas foram condicionais; e 33\% delas foram pagas. Mantendo os sub-recortes do 'Gráfico 1', e separando as alforrias a partir da tipologia que tradicionalmente a historiografia utiliza - gratuita, condicional e pagas -, temos os dados da Tabela 1.

Com efeito, as alforrias condicionais passam a crescer de fato a partir de 1856. É neste ano que acontece um episódio inusitado, mas que trouxe enormes consequências para os escravistas da região, especialmente para aqueles que tinham propriedades dos dois lados da fronteira. No final do mês de agosto, Venâncio José Pereira, delegado de polícia suplente em exercício do distrito de Santana do Livramento, vizinho a Bagé, enviou ao presidente da província algumas questões, devido a uma representação que o subdelegado de polícia do distrito the fez. As perguntas versavam sobre a inviabilidade de aplicação de uma circular imperial ${ }^{17}$ (baseada em parecer de 1856 do Conselho de Estado), naquela 
Tabela 1: Frequência dos tipos de alforria, Bagé (1847-1870)

\begin{tabular}{cccccc}
\hline Anos & Gratuitas & Condicionais & Pagas & $\begin{array}{c}\text { Total de } \\
\text { alforriados }\end{array}$ & $\%$ \\
\hline $1847-1850$ & 12 & 4 & 6 & 22 & 6 \\
$1851-1855$ & 21 & 18 & 24 & 63 & 17 \\
$1856-1860$ & 26 & 37 & 30 & 93 & 25,5 \\
$1861-1865$ & 27 & 38 & 24 & 89 & 24,5 \\
$1866-1870$ & 46 & 17 & 37 & 100 & 27 \\
Total & 132 & 113 & 121 & 367 & 100 \\
$\%$ & 36 & 31 & 33 & 100 & - \\
\hline
\end{tabular}

Fonte: APERS. Livros Notariais de Transmissão e Notas (doravante LNTN) e LNRD. Bagé, 1847-1870.

localidade, que se situava "sobre a linha divisória com o Estado Oriental, cuja divisão de uma estrada de carretas em distância de uma quadra, pouco mais ou menos, das últimas casas da mesma freguesia". As questões foram as seguintes:

1. - Se devem ser postos em liberdade quaisquer escravos que, por qualquer circunstância, passem além da mesma linha divisória, mesmo atrás de animais que sucedem disparar e passar para o Estado vizinho?

2a - Se está no mesmo caso qualquer escravo de proprietários cujas fazendas estão parte no Brasil e parte no referido Estado Oriental?

3a - E, finalmente, se estão no mesmo gozo os escravos que estando ali contratados, voltem, ou passem para o Brasil?

Rogo, pois, a V. Excelência se digne solvê-las, visto como esta delegacia, pela transcendência do assunto, não se crê autorizada para o fazer ${ }^{18}$.

O delegado Venâncio estava bem informado sobre o assunto, pois em nenhum momento ele questiona sobre a liberdade de escravos que fugissem para o outro lado da fronteira. Suas perguntas diziam respeito apenas àqueles cativos que atravessassem a fronteira prestando serviços ao seu senhor. Ao que parece, a resposta foi que sim, se o escravo atravessasse a fronteira com o consentimento do senhor, quando voltasse seria considerado livre - não à toa, principalmente na década de 1870, uma série de alforrias conquistadas na alforria com essa justificativa (por ter ido ao Estado Oriental com consentimento do senhor e voltado ao Brasil) são registradas nos municípios fronteiriços de Alegrete, Bagé, Santana do Livramento e Uruguaiana (MATHEUS, 2012, cap. 4).

Em consonância com esse contexto, notadamente, foi exatamente a partir de 1856 que o número de alforrias condicionais começou a crescer. Nos quase dez anos que se seguiram ao parecer do Conselho de Estado (1856-1865), este tipo de liberdade - aquelas que exigiam mais alguns anos de trabalho ou mesmo a prestação de serviços até a morte 
do senhor(es) - foram as que mais cresceram, atingindo o primeiro posto. O receio dos proprietários de perder seus escravos e, logo, parte de seu patrimônio, era claro. Com isso, tentavam, a partir de alforrias condicionais, manter os trabalhadores atrelados à servidão por mais tempo.

De fato, as informações já deviam estar circulando pela fronteira há algum tempo. Em maio de 1854, dona Clara Bouquem alforriou Maria, de 18 anos, firmando um "contrato" frente o chefe interino do departamento de Taquarembó (no Uruguai) com a liberta. Nele, Clara coloca como condição "servir pelo tempo de 2 anos como até hoje tem feito com fidelidade e boa vontade, tanto no Brasil quanto no Estado Oriental"19.

Já as alforrias pagas só foram maioria logo após o fim do tráfico, entre 1851 e 1855 , quando os preços dos escravos aumentaram, alcançando 38\% do total neste período. Com relação às gratuitas, elas só se tornaram maioria nos anos finais da década de 1840 e na segunda metade da década de 1860, quando chegaram a $46 \%$ do total. Não deixa de ser interessante que esse tipo de manumissão tenha predominado exatamente às vésperas de dois momentos críticos para a instituição escravista - às vésperas do fim do tráfico e da promulgação da Lei do Ventre Livre. Talvez a procura, por parte dos senhores, por lealdade e fidelidade de seus ex-escravos estivesse no cerne desse tipo de alforria, embora possa ser questionado o porquê de essa fidelidade não ser buscada através de manumissões condicionais. É importante lembrar que uma alforria gratuita libertava um escravo, enquanto boa parte dos seus familiares ainda poderia estar presa ao cativeiro. Isso fez com que, quem sabe, aquela manumissão não configurasse um rompimento completo dos laços de dependência, submissão e dominação do agora liberto com a casa senhorial.

No que diz respeito à origem dos escravos alforriados, em 65 registros não havia nenhuma informação sobre tal questão. Contabilizando que todos aqueles que tiveram a cor indicada como pardo ou mulato eram crioulos, 218 (ou 72\%) dos manumitidos eram de nascidos no Brasil, e $28 \%$ eram africanos. Se não somarmos os pardos e mulatos, temos que 158 , ou $66 \%$, eram de crioulos, e 82 , ou $34 \%$, eram africanos. Por seu turno, se abarcarmos apenas o decênio 1847-1856 (97 alforrias), isto é, um período mais próximo ao tráfico atlântico de escravos, o percentual de africanos manumitidos praticamente não muda (33\%). Portanto, a representatividade de africanos alforriados - de $28 \%$ a $34 \%$ - está bastante próxima da representatividade encontrada, para a localidade, em trabalho anterior, mas a partir de inventários e óbitos e também de um censo realizado em 1846 (MATHEUS, 2016, cap. 2).

Já em relação ao sexo dos manumitidos, no geral $61,5 \%$ dos alforriados foram de mulheres, e 38,5\% de homens. O alto percentual de crioulos, por um lado, e de escravas, por outro, alforriados(as) está em sintonia com o observado em outras pesquisas (MATTOS, 1997, p. 15). Contudo, um comentário à parte precisa ser realizado.

Foi no quinquênio 1856-1860 que o percentual de manumissões passadas a escravas e escravos mais se aproximou - 46,5\% delas foram concedidas a cativos. E impressionantes $49 \%$ desses escravos alforriados na segunda metade da década de 1850 o foram de maneira condicional (em dois casos houve a combinação de algum pagamento mais um tempo de serviço a ser prestado). Desses, $87 \%$ tinham 16 ou mais anos de vida. 
Como já foi demonstrado, na Campanha a maioria dos escravos em idade produtiva e do sexo masculino era destinada à lida com o gado. Mesmo assim, os criadores viviam reclamando da falta de mão de obra para a pecuária (MATHEUS, 2012, cap. 1). Logo, para manter a fidelidade de seus cativos, ao que parece, os senhores passaram, a partir de 1856, a conceder alforrias condicionais a homens adultos. Apesar de em somente $2,5 \%$ das alforrias (9 das 367 liberdades) o registro indicar a ocupação do liberto, um desses que recebeu uma alforria condicional nesse quinquênio (1856-1860), Guilherme, cativo de Libindo Antônio Martins, foi expressamente identificado como "campeiro"20. Assim, a suspeita é que os proprietários receavam perder seus trabalhadores a partir do parecer do Conselho de Estado, o que fez com que o padrão de alforrias concedidas se alterasse de maneira substancial e bastante peculiar.

Por seu turno, dos 82 africanos alforriados, em 27 há a informação da nação: 13 deles eram da África Central (4 "Congos", 3 "Benguelas", 2 "Angolas", 2 "Monjolos" e 2 "Cabindas"); 13 da África Ocidental (10 "Minas", 2 "Nagôs" e 1 "Gege"); e 1 "Moçambique". Destas 82 manumissões, 31 (ou 38\%) foram pagas; 26 condicionais (32\%); e 25 gratuitas (30\%).

Desse modo, em primeiro lugar, o percentual de alforrias pagas pelos africanos (38\%) ficou acima das pagas pelos crioulos (32,5\%). Por sua vez, se nos inventários, a partir das informações disponíveis, havia uma presença maior de escravos da África Central, nas alforrias se destacam os cativos da África Ocidental, em função da sua representatividade superar, e muito, sua presença nos inventários (MATHEUS, 2016, cap. 4). Mas não é só. Dentre os 13 alforriados deste grupo de procedência, 9 (7 deles "Minas" - 5 homens e 2 mulheres) pagaram pela liberdade (além desses 9 africanos, somente outros dois, ambos "Congos", pagaram pela manumissão) ${ }^{21}$. Assim, coadunam-se os dois aspectos pontuados acima: os africanos da África Ocidental, em especial os "Minas", eram os africanos que mais alcançavam a liberdade - e o faziam pagando pela mesma. Voltaremos a este tema, ou melhor, às "minas".

De outro lado, entre os crioulos, em 105 registros (ou significativos 66,5\%) há a idade do alforriado. Destes, 34 (ou 32,5\%) tinham de alguns meses de vida até 18 anos. Há aqui, ao nosso ver, um claro indício da participação da família nestas liberdades. Não à toa, há em 30 das 34 manumissões o nome da mãe (ou da mãe e do pai) do alforriado. E, em 26 casos, o registro indica que a mãe e/ou o(s) pai(s) continuava(m) sendo escrava(os) do senhor que alforriava.

Por vezes, o indício da família, ou melhor, de outros familiares atuando em busca da liberdade, é ainda mais sutil. Na alforria da pequena Plácida, de 16 meses, filha natural da parda Laurinda, escravas de Maria Inácia dos Santos, a qual concedeu a liberdade "pelo amor de Deus", o escrivão anotou que copiou do "original a que me reporto em mão da parte, que por haver recebido [...], sendo a apresentante da Carta de Liberdade [a] Avó da liberta de nome Felicidade Maria de Jesus", o que indica a continuidade da relação familiar por no mínimo três gerações. Por sua vez, Maria Magdalena Vinhol libertou Luíza, de 8 anos, em razão da vontade de seu "finado marido como também por ser minha vontade, em atenção ao bom trato e serviço prestado a mim pela liberta Isabel", mãe de Luíza. Pelo mesmo motivo, Romana de Paula Monteiro alforriou gratuitamente e sem condição André, de 18 meses, em 1868, "em atenção aos bons serviços que me tem prestado a mãe [a africana Flora] do mesmo"22. 
Já na alforria da africana Joaquina, de 50 anos, a qual novamente tem relação com o Estado Oriental, três pessoas participaram do acordo: José Cacório, a própria Joaquina e seu senhor, Justino José da Silveira. Conforme Justino, a alforria foi concedida

\begin{abstract}
em atenção aos bons serviços que [Joaquina] me tem prestado, mas com a restrita obrigação de me acompanhar por espaço de três anos a contar de hoje, em qualquer parte aonde eu residir, e com especialidade na Fazenda do Estado Oriental do Uruguai no lugar denominado Rincão entre Gescas e Molhos onde atualmente preexisto. Declaro mais, que em data de 26 de outubro deste ano recebi da mão do preto José Cacório a quantia de 200 patacões de prata de $\$ 966$ cada um [...], cuja quantia gozarei dela pelo tempo de 4 anos, a contar da sobre dita data, como uma compensação da liberdade que gratuitamente dou a minha dita escrava Joaquina, findo cujo prazo, e cumprida a condição deste contrato, entregarei igual quantia, e na mesma espécie, ao dito José Cacório; e caso a preta Joaquina abandone a companhia do primeiro contratante, indiferente de sua vontade, antes do prazo estipulado, fica sem direito de haver do mesmo a referida quantia de 200 patacões $^{23}$
\end{abstract}

Embora não seja possível afirmar qual a relação entre Joaquina e José Cacório, é no mínimo plausivel especular que fossem amásios, ou que tivessem outro tipo de relação parental bastante próximo.

Voltando, daquelas 34 alforrias, seis foram pagas, momento em que o historiador consegue acessar mais facilmente a ação da família no processo de produção da liberdade de um dos seus integrantes. Em 1854, por exemplo, foi registrada a manumissão de "um mulatinho de três meses, pagão [ainda por batizar], filho de nossa escrava Helena e de João Lamotte". O senhor, Antônio Francisco de Camargo, relata que "contratamos com o mesmo pai e recebemos a quantia de 40 mil réis". Da mesma forma, em 24 de janeiro de 1863, o tenente Antônio Luís da Cunha passou a carta de liberdade de Onofre, "filho de uma escrava nossa de nome Fé". No registro, Antônio Luís afirmou que João Jorge da Silva, "que se diz pai do dito Onofre", pagou 9 onças de ouro para que ele fosse liberto na pia batismal. De fato, no mesmo dia 24 Onofre foi batizado, tendo como madrinha a esposa do tenente, dona Lívia Rodrigues da Cunha. Dois meses depois, a carta foi registrada em cartório ${ }^{24}$.

Em novembro de 1858, Augusto José Nogueira, durante o processo de inventário de sua esposa Eufrásia Perpétua Braga, passou a carta de alforria de Abel, de dois meses de idade, filho natural de sua escrava Maria, a qual pagou 40 mil réis (quantia que, nas palavras de Augusto, "recebi da mão da dita minha escrava"), valor pelo qual Abel havia sido avaliado, para que ele fosse, como de fato o foi, batizado como forro. Por sua vez, em setembro de 1867 foi registrada a alforria da parda Inácia, de 3 anos, filha natural de Justina, escravas de Januária Fernandes Lemes. A senhora anotou que concedeu a liberdade "pela quantia de 64 mil réis, que nesta data recebi em moeda corrente"; todavia, não há no registro quem fez o pagamento, ficando subtendido que a mãe, Justina, ou outro familiar pagou pela manumissão25.

Por seu turno, aquele referido protagonismo dos africanos em pagar pela liberdade se fazia presente inclusive nas alforrias de crioulos, isto é, dos seus descendentes. Em 1863, foi registrada a manumissão de Benedito, 17 anos, escravo de Ana da Silva Siqueira, viúva 
de Porfírio Fernandes Siqueira. Na alforria consta que a mãe de Benedito, "a liberta Maria Francisca do Rosário", pagou 600 mil réis pela carta de liberdade de seu filho. No batismo de Benedito, em 1846, não há maiores informações sobre "Francisca", mas no batismo da sua irmã, Luíza, consta que ela era "de nação Nagô"26.

Muitas vezes, esse protagonismo estava solidamente assentado em relações sociais que tinham na origem étnica, mesmo naquele recanto do Brasil oitocentista, um traço fundamental. E foi exatamente em um processo-crime que envolveu a "africana mina" ("nagô" no parágrafo acima), Maria Francisca do Rosário, liberta, que identificamos tal questão. Durante os interrogatórios, fica evidente uma rede de africanas minas que colaboravam umas com as outras, seja para a obtenção de matéria-prima para produção de doces e salgados (a "quitandeira" Maria Francisca do Rosário fornecia açúcar e farinha de trigo para a também "mina" Maria, escrava de dona Ana de Oliveira Machado, à qual tinha que pagar apenas depois de vender seus produtos), quanto para conquista da liberdade (a mesma Maria, pertencente a Ana Machado, além de depositar seu dinheiro com "a Mana Chica" ou "Tia Chica", duas das alcunhas de Maria Francisca do Rosário, havia combinado com a "africana mina" Joana, escrava de João Antunes Maciel, sua "mana", que a primeira que conseguisse a permissão do seu senhor para se alforriar, e parte dos recursos para tanto, pegaria o dinheiro que faltasse com a outra e compraria sua liberdade - depois, a já liberta, retribuiria o favor) ${ }^{27}$.

$\mathrm{Na}$ verdade, relações sociais e familiares se entrelaçavam, ajudando a produzir liberdades. Em 1855, foi registrada a manumissão da "preta Senhorinha", filha da "preta Bárbara Fagundes, de nação Congo, hoje liberta", escrava de Jacinto Fagundes de Souza. Pela liberdade de Senhorinha foram pagos "300 patacões prata porque foi comprada a escrava Firmina, de nação, que me foi dada em troca por seu senhor Dionísio José Leal, marido da dita preta Bárbara". O tabelião registrou a liberdade em um livro de notas e entregou a carta em mãos do "apresentante", Dionísio José Leal. Desta feita, Bárbara, além de provavelmente continuar mantendo algum tipo de relação com Jacinto, pois mantinha o sobrenome senhorial, era casada com Dionísio José, preto forro com importante projeção social na localidade, o qual estava inserido em uma intricada rede de relações de compadrio, rede na qual alguns libertos concentravam boa parte dos apadrinhamentos. Aliás, por duas vezes Bárbara foi madrinha ao lado do marido (MATHEUS, 2016, cap. 5). Em uma 'Lista de Qualificação de Votantes' de meados da década de 1870, Dionísio foi indicado no campo 'Saber ler?' como "sabe". Por fim, Dionísio era um dos membros mais importantes da Irmandade do Rosário da localidade, como mostra um abaixo assinado direcionado à presidência da província ${ }^{28}$.

Dessa mesma rede advém outra liberdade, que talvez também tenha tido nos laços familiares fator decisivo. Em 1847, foi produzida a carta de alforria de Felizarda, escrava de João Batista de Meirelles e Ana Correia de Meirelles. Conforme os senhores, Bernabé Fagundes (também irmão da Irmandade do Rosário), padrinho de casamento de Dionísio José Leal, apresentou-se para libertar Felizarda, para o qual "Ihe exigi 400 patacões prata pela minha escrava, e anuindo a esse trato, me entregou o dito Fagundes em dinheiro [...] 105 patacões também prata e nos passa um fica do excedente". Os Meirelles deram 18 meses de prazo para Bernabé quitar o restante e, em agosto de 1849, passaram um "recibo" ao mesmo. Todavia, a manumissão só foi registrada em cartório em 1854. Ao final 
do assentamento, foi registrado o dito recibo, no qual os senhores atestam que receberam "de Bernabé Fagundes 400 patacões prata que me deu pela alforria de [...] Felizarda". Cinco anos depois, Bernabé e Felizarda formalizaram sua união perante a Igreja 29.

Em realidade, a família parece ter sido o principal recurso para que muitos escravos alcançassem a liberdade. Não obstante João José Reis postule que a conquista da alforria era um meio tradicional "de emancipação individual" ${ }^{30}$, grosso modo, muitas vezes a sua obtenção era produto de uma ação coletiva, assim como a consequência de sua efetivação tinha efeitos que poderiam se espraiar e repercutir na vida de outras pessoas ao redor do liberto (uma forra geraria filhos livres, assim como um forro poderia vender seu trabalho e angariar mais recursos, enquanto livre, os quais poderiam beneficiar um filho ou alguém de seu grupo de convivência). Por isso, neste momento, antes de continuarmos, impõe-se uma rápida digressão em direção a um debate deveras mencionado pela historiografia, que tem na família, ou na família escrava, o seu ponto central.

Com efeito, há diferentes interpretações sobre a função sociológica que a família (escrava) exercia sobre o sistema como um todo. No famoso debate proposto por Robert Slenes, em sua obra Na senzala uma flor, o autor sugere que a família escrava - "nuclear, extensa, intergeracional - contribuiu decisivamente para a criação de uma 'comunidade escrava'". Conforme Slenes, muito embora os senhores tentassem constantemente, através de uma "política de incentivos", corroer as bases de solidariedade entre os cativos (estabelecendo uma "competição por recursos limitados"), a família cativa serviu como contraponto, minando "constantemente a hegemonia dos senhores" e "criando condições para a subversão e a rebelião" (SLENES, 1999, p. 48).

Nesse sentido, a partir do seu ponto de vista, Robert Slenes contesta Manolo Florentino e José Roberto Góes, apontando que a família escrava não pode "ser considerada um fator estrutural na manutenção e reprodução do escravismo" (SLENES, 1999, p.50). Florentino e Góes, por sua vez, observaram que "a recriação da sociedade escravista era uma questão política, e as relações familiares escravas cumpriam papéis políticos" (FLORENTINO e GÓES, 1997, p. 31).

Por sua vez, Robert Slenes discordou de Hebe Mattos quanto ao processo de produção de identidade(s) e de laços de convívio por parte dos escravos. Mattos compreende que a vida em família, e especialmente em comunidade, antes aproximou o escravo de uma visão de liberdade do que forjou uma identidade étnica a partir da experiência do cativeiro. De acordo com a autora, nem a família nem a comunidade de cativos seriam as "matrizes de uma identidade negra alternativa ao cativeiro", já que o cotidiano neste (no cativeiro) tendia a valorizar a construção de identidades sociais outras que não aquelas impostas pela condição cativa (MATTOS, 1995, pp. 141-151).

É justamente essa hipotética aproximação dos escravos "ao mundo dos livres, via construção de laços de parentesco e dependência", que Robert Slenes contesta. Para o autor, ela demandaria "muito tempo", sendo, portanto, menos importante que os laços de solidariedade construídos no interior do cativeiro. Slenes complementa, observando que, especialmente no sudeste, não havia uma distância cultural tão grande entre africanos e crioulos, já que estes seriam, em grande medida, filhos daqueles (SLENES, 1999, p. 52; e 2012). 
É impressionante como quase todos os trabalhos (artigos, dissertações, teses) que tratam da questão da família escrava abordam o debate proposto por Robert Slenes como um debate, mesmo que nenhum dos dois autores provocados tenha respondido o convite ao debate (e a 1ำ edição de Na Senzala uma flor é de 1999). Em outra oportunidade, já apontamos o quão complicado é resumir a complexa obra de Manolo Florentino e José R. Góes à tese de que a família contribuía apenas para a paz entre os escravos, e entre escravos e seus senhores (MATHEUS, 2012, cap. 3).

Para além do fato de que a pesquisa de Manolo Florentino e José R. Góes tem um recorte temporal bastante específico (fins do século XVIII até meados do século XIX), o qual caracterizou-se por uma enorme entrada de africanos no Rio de Janeiro (lócus do estudo dos autores), não pode passar despercebido que, para eles, "a cooperação entre os cativos deve ter sido fundamental, em primeiro lugar, a eles próprios". De acordo com Florentino e Góes, a família cativa, "sem se constituir em instrumento direto de controle senhorial", servia "como elemento de estabilização social, ao permitir ao senhor aferir uma renda política". Logo, cremos, a "paz" postulada pelos autores não pressupõe uma sociedade sem conflitos, mas sim uma busca dos escravos em "construir laços de solidariedade e de auxílio mútuo que os ajudasse a sobreviver no cativeiro" da melhor forma possível, após o brutal desenraizamento (social) e trauma (com a travessia) que sofreram (FLORENTINO e GÓES, 1997, pp. 35-36 e 175 - grifo nosso). Da mesma forma, como exposto na análise realizada há pouco das alforrias, cremos que tem razão Hebe Mattos em afirmar que "os escravos inseridos em redes familiares" tinham mais recursos do que outros cativos (MATTOS, 1995, p. 162).

Enfim, o que gostaríamos que ficasse retido é que, naquele contexto rural, de economia baseada na pecuária, a alforria era uma possibilidade não muito mais distante (às vezes à frente) do que em outras regiões do Brasil oitocentista. Contudo, alguns recursos, como sólidos laços de parentesco, eram essenciais para que o trânsito entre a escravidão e a liberdade fosse menos difícil e o passo decisivo na ascensão social de um escravo fosse possível.

\section{Os senhores que alforriavam}

Como dito anteriormente, no geral, quando a historiografia trata do processo de passagem da escravidão para liberdade, foca-se quase que exclusivamente nos escravos, buscando, como fizemos no tópico anterior, nas características dos libertos os meandros pelos quais liberdades eram produzidas. Grosso modo, pouca atenção é dada aos senhores que alforriavam. Neste sentido, com objetivo de tentar compreender esse processo de maneira holística e com um pouco mais de complexidade, analisamos agora os proprietários que concederam cartas de alforria aos seus cativos. Quem eram eles? Senhores, senhoras, ou o casal aparecia lado a lado alforriando?

Da mesma forma, tentamos responder qual a envergadura dos senhores que alforriaram: pequenos, médios ou grandes proprietários? Para tanto, cruzamos os dados extraídos das alforrias com dois bancos de dados, um construído a partir dos inventários post mortem e outro elaborado a partir dos registros de batismos. De posse de deles foi possível observar como estava distribuída a estrutura de posse escrava. Resumidamente, é 
possivel dizer que a posse cativa estava amplamente disseminada pelo tecido social, com o predomínio de pequenas escravarias. Por outro lado, um pequeno grupo (notadamente os grandes criadores de gado) concentrava cerca de $1 / 4$ de todos os escravos da localidade ${ }^{31}$.

Importante esclarecer que o foco foi a familia senhorial, isto é, quando uma senhora apareceu em uma alforria, e em outro momento seu marido foi quem passou a manumissão; juntamos os dados e tratamos o casal como um proprietário (aos que preferirem, uma casa senhorial). Claro que, para tanto, tivemos que cruzar também as informações dos batismos (em que temos o casal senhorial batizando os seus filhos) com as das manumissões.

Cremos que seja necessário conhecer quem alforriava para melhor entender o processo de produção de liberdades, já que esta era uma prerrogativa senhorial. E mais: não conhecer minimamente as características dos proprietários que concediam manumissões para alguns de seus escravos dificulta a compreensão dos processos de diferenciação e hierarquização social, pois estes estavam calcados, em grande medida, na própria existência da escravidão, ou seja, na posse ou não de cativos. E a grande maioria de proprietários, na realidade aqui estudada, era de pequenos senhores ${ }^{32}$. Logo, esses pequenos proprietários se desfaziam de suas posses via alforria? Com que intensidade e sob quais parâmetros?

As 350 cartas de alforrias registradas, entre 1847 e 1870, nos cartórios de Bagé, contendo 367 liberdades, foram concedidas por 272 proprietários. Estes estiveram distribuídos em 129 senhores, 83 senhoras, 49 casais e 9 herdeiros (geralmente cumprindo alguma verba testamentária ou mesmo alguma última vontade informal do falecido[a]). No geral, quase metade $(47,5 \%)$ dos senhores que manumitiam eram homens, como é possivel observar na 'Tabela 2'.

Retomando algo discutido em trabalho anterior (MATHEUS, 2016, cap. 4 e anexo 5), quando da análise da estrutura de posse a partir dos batismos, se observarmos o percentual de senhoras que aparecem nos batismos - 30,5\% entre 1830-1850, 26\% na década de 1850 , e $28 \%$ nos anos 1860 -, é possível verificar que, nas cartas de alforrias, essa representatividade se reproduz. Nas pouco mais de duas décadas que dispomos dos registros de manumissões em cartório, cerca de um terço dos proprietários que concederam liberdades foram mulheres.

Tabela 2: Senhores que alforriaram, Bagé (1847-1870)

\begin{tabular}{cccccc}
\hline- & Senhores & Senhoras & Casais & Herdeiros & Total \\
\hline № de alforrias & 130 & 84 & 49 & 9 & 272 \\
$\%$ & 47,5 & 31 & 18 & 3,5 & 100 \\
\hline
\end{tabular}

Fonte: APERS. LNTN e LNRD. Bagé, 1847-1870.

Evidentemente, e repetindo o dito anteriormente, há neste contexto uma variedade de situações. Essas senhoras podiam ser chefes de fogos (viúvas ou solteiras) ou mulheres casadas que tinham responsabilidade por uma parte da escravaria (talvez aqueles cativos mais próximos à casa senhorial, como mucamas, costureiras, cozinheiras, etc.). Isso aponta para um redirecionamento do papel da mulher naquele mundo rural - algo que foge aos 
objetivos mais imediatos do presente estudo - pois, mesmo que algumas delas estivessem inseridas em relações do tipo patriarcais, elas exerciam importantes funções de mando, quando não com uma grande autonomia (sobre a mesma questão, ver SOARES, 2009, p. 90).

Reforçando o exposto acima, por volta de $18 \%$ dos que alforriaram foram casais. Portanto, as senhoras participaram, de uma forma ou de outra, de cerca de metade das manumissões. Por sua vez, no cômputo geral, elas foram responsáveis por 124 (ou 34\%) das 367 liberdades concedidas, percentual levemente superior à sua representatividade nas manumissões. Já os senhores passaram 164 (44,5\%), e por fim os casais concederam 70 liberdades, ou 19\% (herdeiros passaram 9 alforrias, ou uma liberdade em cada uma delas).

No que diz respeito à relação dos senhores que alforriavam com a estrutura de posse, conseguimos identificar 153 deles nos batismos e 55 nos inventários. Deste total, 37 foram encontrados nos batismos e nos inventários, sendo que a maioria (24) estava na mesma faixa de plantel. Apenas dois tiveram uma grande discrepância (isto é, em uma fonte o proprietário seria classificado como um grande senhor, e em outra como um pequeno senhor): dona Ana Helena Correia de Borba, cujo inventário foi produzido em 1879, teve 4 escravos arrolados no mesmo, enquanto que nos batismos, entre 1846-1871, nada menos do que 33 cativos foram anotados; já Nicolau Antônio Pereira, no seu inventário datado de 1874, teve 7 cativos arrolados, e nos registros de batismos, também entre 1846-1871, 20 escravos aparecem como pertencendo a ele ${ }^{33}$.

Antes de passarmos para o resultado encontrado a partir do cruzamento das informações das alforrias com os inventários e os batismos, é fundamental fazer dois esclarecimentos. O primeiro, e mais importante deles, é que na estrutura de posse conforme os batismos não nos detivemos em recortes. Portanto, quando localizamos nos registros de batismo um senhor que concedeu uma alforria, buscamos todos os escravos pertencentes a ele anotados nos batismos, independente da década. Logo à frente voltaremos a essa questão.

Por outro lado, nada menos do que 87 proprietários que concederam manumissões não foram encontrados em uma fonte, nem em outra. Ou seja, mesmo a grande quantidade de senhores encontrada nos registros de batismo (provavelmente, para além de listas de fogos, a fonte que mais captura esse grupo social) não dá conta da totalidade de proprietários que habitavam uma localidade do Brasil de então.

Dito isso, na 'Tabela 3', podemos observar a relação entre a estrutura de posse e os senhores que alforriaram. Tanto nos inventários quanto nos batismos predominaram, entre os que passaram manumissões, os pequenos proprietários, o que no geral está de acordo com o tamanho das escravarias identificadas. Para Porto Feliz, na primeira metade do século XIX, Roberto Guedes encontrou 51,5\% de pequenos senhores alforriando. Por seu turno, o autor identificou que quase $30 \%$ dos que alforriavam eram grandes proprietários. Se, por um lado, em ambas as localidades havia predomínio de pequenos senhores libertando, por outro as diferenças podem estar ligadas às fontes utilizadas (aqui batismos e inventários, e para Porto Feliz listas de fogos e testamentos) e também ao desempenho econômico das regiões, o que também vale para a comparação a seguir ${ }^{34}$.

Para Campinas, Lizandra Ferraz, através dos processos de herança, verificou que na primeira metade do século XIX quase $19 \%$ das alforrias foram concedidas pelos pequenos 
proprietários (utilizando as classificações do nosso estudo), 21\% pelos médios, e mais da metade do total pelos grandes escravistas. Já na década de 1860, a autora observou que o quadro quase não se alterou (21\%, $17,5 \%$ e mais de $60 \%$, respectivamente). Porém, cerca de $67 \%$ das manumissões estavam concentradas em escravarias com até 30 cativos, em ambos os períodos (FERRAZ, 2010, pp. 134-137) . $^{35}$.

Analisando as diferenças de possibilidade de conquista da alforria entre pequenas e grandes (as plantations) propriedades no sudeste ao longo do século XIX (mesmo cenário estudado por Roberto Guedes e Lizandra Ferraz), Robert Slenes argumentou que havia dois contextos bastante diferentes, o que implicava diferenças no grau de produção de liberdades: muitos pequenos senhores com uma quantidade expressiva de crioulos adultos, e grandes proprietários de escravos com muitos africanos. Conforme Slenes, nas primeiras a prática de manumitir "parece ter sido muito mais comum ". Tal assertiva, por um lado, ajuda a explicar em parte os números encontrados por Roberto Guedes e Lizandra Ferraz, e por outro lado serve como base argumentativa para que, no contexto apreciado pelo autor (de novo, as plantations do sudeste), tenha surgido uma identidade escrava baseada na experiência comum do cativeiro e também em uma herança cultural centro-africana (ou banto) em oposição à identidade senhorial (SLENES, 2012, pp. 107-115 e nota 8).

Voltando a Bagé, nos inventários a representatividade dos senhores com até 9 cativos, encontrada a partir da estrutura de posse, ficou entre $65 \%$ e $77,5 \%$, entre c.1830-1850, 1851-1860 e 1861-1870, percentual próximo ao encontrado nas alforrias (67\%). Já os médios proprietários que manumitiram perfizeram $25,5 \%$, enquanto na estrutura de posse esse percentual ficou ente $17,5 \%$ e $23,5 \%$. Finalmente, a representatividade dos senhores com 20 ou mais escravos que passaram alforrias ficou em 7,5\%, de modo que nos inventários ela variou entre $5 \%$ e 11,5\%. Por outro lado, se focamos nas liberdades concedidas, o percentual de grandes senhores praticamente dobra (de 7,5\% para 14\%), o de médios quase permanece inalterado (de 25,5\% para 24,5\%), e os proprietários com até 9 escravos caem de $67 \%$ para $61,5 \%$. Portanto, conforme os inventários, os proprietários com 20 ou mais escravos alforriavam, ou melhor, passavam três vezes mais liberdades do que sua representatividade no total de senhores.

Tabela 3: Envergadura dos senhores que concederam alforrias/liberdades, Bagé (século XIX)

\begin{tabular}{lcccccc}
\hline $\begin{array}{l}\text { Estimativa do } \\
\text { tamanho dos } \\
\text { plantéis }\end{array}$ & $\begin{array}{c}\text { Nos } \\
\text { inventários }\end{array}$ & $\begin{array}{c}\text { \% de } \\
\text { alforrias }\end{array}$ & $\begin{array}{c}\text { \% das } \\
\text { liberdades }\end{array}$ & $\begin{array}{c}\text { Nos } \\
\text { batismos }\end{array}$ & $\begin{array}{c}\text { \% de } \\
\text { alforrias }\end{array}$ & $\begin{array}{c}\text { \% das } \\
\text { liberdades }\end{array}$ \\
\hline $\begin{array}{l}\text { Com 1 a } 9 \\
\text { escravos }\end{array}$ & 37 & 67 & 61,5 & 121 & 79,5 & 79,5 \\
$\begin{array}{l}\text { Com 10 a 19 } \\
\text { escravos }\end{array}$ & 14 & 25,5 & 24,5 & 17 & 11 & 9,5 \\
$\begin{array}{l}\text { Com 20 ou } \\
\text { mais escravos }\end{array}$ & 4 & 7,5 & 14 & 14 & 9,5 & 11 \\
Total & 55 & 100 & 100 & 152 & 100 & 100 \\
\hline
\end{tabular}

Fonte: APERS. LNTN e LNRD. Bagé, 1847-1870. 
Por sua vez, nos registros de batismo, os grandes senhores perfizeram 9,5\% dos que concederam alforrias, bem acima do $1 \%$ de sua representatividade na mesma fonte. $\mathrm{Na}$ outra extremidade, os pequenos proprietários passaram 79,5\% das manumissões, abaixo dos $92 \%$ de senhores nos batismos com até 9 escravos. Por fim, os percentuais que mais se aproximam foi o de médios senhores, que concederam $11 \%$ das alforrias, enquanto representavam $7 \%$ dos proprietários que tiveram algum cativo registrado nos batismos. De outro lado, focando apenas das liberdades concedidas, nenhum percentual se altera significativamente - pequenos senhores continuaram representando $79,5 \%$ das liberdades, médios passando de $11 \%$ para $9,5 \%$, e grandes proprietários de $10 \%$ das alforrias para $11 \%$ das liberdades.

Cremos que essa aproximação entre o resultado alcançado conforme os inventários e os batismos, embora haja uma significativa diferença entre os médios senhores que alforriaram, deve-se ao fato de que, neste momento, não nos detivemos em recortes específicos ao apreciar os batismos, o que fez com que crescesse especialmente o percentual de grandes (com 20 ou mais escravos) proprietários. Cabe enfatizar que, na estrutura de posse a partir dos batismos por recortes, a representatividade dos grandes senhores era de $1 \%$, sendo que nas alforrias ela alcançou $9,5 \%$ das manumissões e $11 \%$ das liberdades.

Enfim, médios e grandes senhores, de acordo com os inventários, e os grandes proprietários, segundo os registros de batismo, alforriaram acima de sua representatividade nessas mesmas fontes. De outro modo, em números absolutos, os pequenos proprietários foram, de longe, os que mais concederam alforrias/liberdades. Esse resultado era de se esperar, já que tratamos de uma região onde predominavam as pequenas escravarias. Entretanto, esse processo não era simples. Em uma sociedade em que o status e a diferenciação social estavam, em grande medida, baseadas no senhorio de outras almas, para um pequeno senhor de escravo(s) alforriar um(a) cativo(a) podia ser um passo decisivo para sua queda na hierarquia social e/ou para a desarticulação de sua pequena produção. Por isso, alguns senhores adotavam lógicas outras na relação com seus cativos e no momento de conceder manumissões. Vejamos alguns exemplos.

Aparentemente contraditório, pois senhor de uma grande escravaria, o exemplo de Manoel José da Rosa nos ajuda a entender o que estamos argumentando. Na prática, Manoel da Rosa era um grande proprietário, já que teve 20 escravos arrolados nos registros de batismo entre 1834 e 1871 . Todavia, um olhar mais próximo nos informa que todo esse plantel era originário de um ventre. Ou melhor, de dois, mas um gerado a partir de outro. Manoel e sua esposa, Epifânia da Rosa Ribeiro, eram senhores de Dionísia, doada a eles pela mãe de Epifânia, Ana Joaquina de Jesus.

Entre 1834 e 1853, Dionísia levou à pia batismal cinco filhos. No mesmo ano do batismo da última filha de Dionísia, a primogênita, Faustina, também batizou um filho, Nasário, neto de Dionísia. Exatamente no mesmo dia do batismo de Nasário, então com dois anos, 30 de julho de 1853, foi registrada a carta de alforria da "peta crioula" Dionísia, a qual pagou "32 patacões", quantia "por mim [Manoel da Rosa] a ela pedida", pela sua liberdade. O tabelião conferiu a carta de alforria, escrita em 11 de junho por Manoel, e a entregou "em mão da liberta", que provavelmente aproveitou a ida à vila para batizar o neto e para registrar sua manumissão. 
Depois de Nasário, Faustina levou mais onze filhos à pia batismal entre 1854 e 1871. Assim, como sua mãe, em abril de 1876 a "crioula" e "cozinheira" Faustina pagou 300 mil réis pela sua liberdade. Além de Dionísia e Faustina, Manoel José da Rosa alforriou apenas mais um escravo, o africano José de "mais de 50 anos", em dezembro de 1870, em "atenção aos bons serviços que me tem prestado"36.

Não sabemos se, além de José, todos os escravos de Manoel da Rosa originaram-se de Dionísia, mas é fato que não encontramos mais nenhum cativo do casal nos batismos para além dos filhos e netos de Dionísia, ao longo de três décadas e meia. Assim, ao que parece, Manoel só alforriou a matriarca da família escrava quando sua filha mais velha, Faustina, começou a ter filhos. Da mesma forma, dentro da mesma lógica, só alforriou Faustina depois de ela ter garantido consistentemente a reprodução do seu plantel.

Nesse mesmo contexto, alguns pequenos proprietários estrategicamente passavam alforrias apenas no final da vida - ou, condicionalmente, quando viessem a morrer, garantindo o status senhorial enquanto eram vivos e atendendo à aspiração de alguns escravos que buscavam na alforria uma forma de projeção social. Foi o caso de José Antônio Pacheco.

No seu inventário, de 1868, nenhum escravo foi arrolado. Porém, nos batismos, José Pacheco aparece como senhor uma vez: em 1864, seu escravo Vicente, serve como pai espiritual da pequena Maria Angélica, filha natural de Mariana, cativas de João Anacleto Gularte. Quase dez anos antes, em 1855, foi registrada a alforria de Vicente, na qual José concede a liberdade "com a condição, porém, de servir e acompanhar como até aqui o tem feito durante todo o tempo de minha vida"37.

O comerciante Luís Vinhol, vinculado à rede de compadrio de libertos mencionada anteriormente, e sua esposa, Maria Magdalena Vinhol, libertaram três escravos na primeira metade da década de 1860: Isabel e seus dois filhos, Camilo e Luíza. Camilo foi alforriado gratuitamente em setembro de 1861, quando recém havia completado um ano de vida; Isabel, em 1862, pagou 1 conto e 200 mil réis pela sua liberdade; e a filha mais velha, Luíza, foi manumitida em razão do bom "serviço prestado a mim pela liberta Isabel[...], com a única condição de estar em minha [de Magdalena] companhia enquanto eu for viva, não podendo arredar-se salvo quando casar com pessoa que para isso tenha meu consentimento, e for indispensável tal separação". Assim, repetiu-se o caso de José Antônio Pacheco: no inventário de Luís Vinhol, em 1867, nenhum escravo foi arrolado38.

Em 1857, Francisca Joaquina Xavier libertou em testamento e por cartas de alforrias a africana Catarina e seus filhos, Plácida, Marcos, Plácida e André, notadamente quase todos os seus escravos - liberdades essas que foram registradas no mesmo ano do inventário e com a condição de servirem até "até a morte da senhora". Quase, pois, para resolver um conflito com a sua filha e o seu genro, Francisca entregou dois escravos a estes (cativos que também não aparecem no inventário) ${ }^{39}$.

Feliciana Joaquina Jorge, em cujo inventário foram arrolados dois escravos, o "africano domador" Joaquim e a "crioula da Bahia" Leonor, libertou a última em verba testamentária, cumprida em carta de alforria após sua morte, no mesmo ano do inventário (1853). É o mesmo caso de Emerenciana Joaquina dos Santos, que libertou condicionalmente (a sua morte) dois de seus 3 cativos após sua morte ${ }^{40}$. 
Mas o que esses exemplos nos revelam? Inseridos naquele contexto (uma sociedade escravista, em que a concessão de alforrias era um costume amplamente difundido, mas em que o status social estava em grande medida assentado na posse de outros indivíduos), mesmo os pequenos senhores - amiúde, a grande maioria dos proprietários - não podiam ficar alheios a essa situação. Assim, estratégias outras de reprodução de suas escravarias e de atendimento aos anseios de seus escravos, que de resto estavam a par do contexto social que os cercava, deveriam ser elaboradas.

Não à toa, por outro lado, os quatro grandes senhores - identificados a partir dos inventários, dois pertencentes à família Martins e dois à família Netto, duas das mais tradicionais da fronteira ao longo do século XIX - que alforriaram o fizeram de maneira gratuita ou paga. Das 12 manumissões encontradas de José de Souza Netto (o maior escravista da localidade) e sua esposa, de seu filho Domingos Netto (o maior montemor), de José Luís Martins e de Domingos Martins, 3 foram pagas e 9 gratuitas. E mais: praticamente todas foram de cativos adultos ${ }^{41}$.

Ao que parece, esses proprietários com maiores cabedais não precisavam se preocupar tanto com questões como o risco de deixarem de ser senhores. Assim, poderiam alforriar ou por uma demanda dos escravos cobrando por isso, ou por iniciativa própria em razão dos bons serviços e/ou uma maior proximidade com algum cativo.

Confirmando o postulado acima, das 24 alforrias concedidas por grandes proprietários, mas a partir dos batismos, 22 (ou quase 92\%) foram pagas ou gratuitas. E, ainda assim, uma das únicas duas condicionais o foi com um ar deveras patriarcal (ou matriarcal, no caso). Em janeiro de 1854 (a carta foi registrada em maio de 1855), dona Felisbina Francisca de Oliveira, que teve 22 escravos anotados nos batismos, libertou a parda Generosa com a

\footnotetext{
obrigação porém de acompanhar-me durante a minha vida; e se por a caso a dita escrava durante minha vida ou por minha morte venha a casar-se poderá escolher uma de suas Senhoras Moças para viver na companhia dela, caso do futuro marido isso the convenha, aliás o poderá acompanhar para onde a queira levar ${ }^{42}$
}

Do ponto de vista senhorial, a tutela sobre Generosa estava garantida. Além de ter que ficar com sua senhora enquanto esta fosse viva, depois de casar poderia escolher viver com uma das filhas de Felisbina, ou acompanhar o marido "para onde [ele] a queira levar".

Por outro lado, e pegando somente os pequenos senhores assim identificados de acordo com os inventários (menos dona Ana Helena Correia e Nicolau Pereira, os quais foram classificados como grandes senhores segundo os batismos, mas pequenos conforme os inventários), o percentual de condicionais cresce significativamente, tornando-se maioria. Nada menos do que $40,5 \%$ das liberdades concedidas por pequenos senhores tiveram alguma condição (60\% delas por uma senhora e/ou por um casal), percentual acima dos cerca de $30 \%$ que as condicionais tiveram entre todas as liberdades (ver 'Tabela 1'). Por seu turno, outras $32,5 \%$ das alforrias foram pagas. Aliás, uma dessas "pagas" teve como característica a reposição (condição senhorial?) da alforriada: em 1847, Manoel Pinheiro e sua esposa alforriaram Silvéria "por nos haver a mesma escrava indenizado com outra, que em nosso serviço doméstico suas vezes faça, cuja escrava por nome Maria Joaquina com que nos indeniza"43. 
Portanto, apresenta-se um quadro em que, para entendermos o processo de passagem para a escravidão de forma holística - isto é, tentando conhecer não apenas os cativos manumitidos mas também quem eram os proprietários que alforriavam -, primeiramente é preciso levar em conta o fundamental papel que as senhoras desempenhavam naquela realidade. Por sua vez, grandes proprietários tendiam a alforriar gratuitamente ou cobrando um valor pela manumissão. Por outro lado, pequenos senhores e, principalmente, senhoras colocavam alguma condição (geralmente o/a acompanhar até sua morte), ou cobravam pela alforria. No final desse artigo, retomaremos a partir de um caso específico, mas do ponto de vista qualitativo, essa interessante questão (senhoras com pequenas escravarias alforriando condicionalmente).

Finalmente, esse padrão está em acordo com o observado em trabalho anterior. Nele, vimos que a elite econômica, especialmente a elite entre os criadores de gado, detinha as maiores escravarias da localidade, muito embora os cativos perfizessem a menor parte de suas fortunas. Por seu turno, boa parte do patrimônio dos pequenos e menos aquinhoados senhores estava localizado exatamente na posse de escravos; logo, alforriar um cativo que fosse não era algo simples para esses proprietários, e por isso deveria ser muito bem pensado, ou ao menos recompensado, garantindo o trabalho(a) do escravo(a) por mais tempo ou o seu valor como indenização (MATHEUS, 2016, cap. 3 e 4).

\section{Últimas palavras}

Para encerrarmos, analisamos um caso que abarca a multiplicidade de fatores que estavam envolvidos na produção de liberdades, bem como aspectos outros que tratamos ao longo do texto. Em 1862, foi registrada uma alforria coletiva, em que foram libertados a crioula Leonor, principal personagem do enredo aqui narrado, de 59 anos, o africano Joaquim, também de 59 anos e possivel amásio (e pai dos filhos) de Leonor, Maria, de 34 anos, e o pardo Gregório, de 12 para 13 anos. A condição imposta pelo senhor, Augusto José Nogueira, era a de que os escravos trabalhassem para ele até "o seu falecimento". Nogueira declarou que "todos os filhos que a parda minha dita escrava Maria tiver da data desta Carta de Liberdade em diante até meu falecimento é minha vontade que fiquem também forros" 44 .

$\mathrm{Na}$ alforria, não há nenhuma informação sobre o parentesco dos libertos; no entanto, através de dados extraídos dos registros de batismos e de outra manumissão, que analisamos mais à frente, ficamos sabendo que Leonor era mãe de Maria, a qual era mãe de Gregório - a quem a avó, Leonor, serviu como madrinha. Além de Gregório, Maria levou mais seis filhos à pia batismal, sendo que apenas um, Pedro Maria, após a manumissão coletiva e, logo, já batizado como forro. Um dos ainda batizados como escravo foi Florêncio, nascido em outubro de $1853^{45}$.

Cerca de seis anos após a alforria coletiva, em junho de 1868, foi registrada a manumissão de Florêncio quando este tinha quase 14 anos. Curiosamente, se a prática discursiva senhorial foi a mesma da geralmente empregada pelos que alforriavam, o nome da proprietária, digamos assim, e a obrigação imposta por ela chamam atenção. Acompanhe o leitor o conteúdo da manumissão: 


\begin{abstract}
Eu, a parda Leonor, escrava do senhor Augusto Nogueira Picanço, declaro que sou senhora e possuidora de um escravo também de cor parda, de nome Florêncio de 13 anos de idade, o qual é meu neto, filho natural de minha filha parda Maria, também escrava do mesmo Senhor Augusto, cujo escravo eu obtive por compra que dele fiz não só ao referido meu senhor Augusto Nogueira Picanço, como também aos herdeiros Bento José Nogueira e Dona Felizarda Nogueira, ao qual escravo de minha livre e espontânea vontade e sem constrangimento de pessoa alguma concedo a liberdade para que dela goze unicamente depois do meu falecimento ${ }^{46}$
\end{abstract}

Cremos que qualquer análise maniqueísta sobre a condição imposta por Leonor tenda a ser anacrônica. Provavelmente seu maior desejo era ver o neto, já entrando na idade adulta (do ponto de vista senhorial, em idade produtiva), livre - aliás, poderiamos nos perguntar por que Florêncio não entrou junto na alforria coletiva, registrada em 1862, embora seja impossivel responder a tal questão.

Porém, para tanto, Leonor empregou boa parte dos seus esforços e recursos para assegurar a liberdade de Florêncio, e consequentemente precaver-se, garantindo que alguém lhe ajudasse na manutenção do seu sustento e da sua subsistência em plena velhice, mesmo que atrelando o próprio neto a uma obrigação de liberto condicional. Não nos parece fora de propósito, nem muito distante daquela realidade, em que eram as relações sociais e de dependência pessoal que ditavam a dinâmica social. O caso de Leonor e seu neto nos remete à pawnship africana, em que era comum pais, irmãos ou outros parentes com ascendência sobre determinado indivíduo, por diferentes motivos, forçá-lo a uma servidão temporária (FERREIRA, 2012, pp. 81, 101 e 125; LOVEJOY e RICHARDSON, 2003, p. 40 e nota 89 na p. 52). De resto, isso aproxima a avó de Florêncio àquelas pequenas senhoras que libertavam condicionalmente seu(s) escravo(s).

Da mesma forma, ao que parece, a relação de proximidade e confiança entre a família de Leonor e a do senhor Augusto José Nogueira não era mera retórica. No testamento de Augusto, produzido em 1874 e aberto nove anos depois, ele instituiu "o pardo Gregório, que foi meu escravo, filho da parda Maria" como "herdeiro de uma parte de campo na fazenda São Luís [...], cuja parte de campo será colocado na minha terça [...], e isto faço em remuneração aos bons serviços que sempre me tem prestado o mesmo pardo Gregório". Como o testador havia falecido, quem apresentou o testamento em juízo para que as últimas vontades de Augusto fossem cumpridas foi o próprio Gregório ${ }^{47}$.

O caso acima demonstra que, para além de possíveis cruzamentos e relações com dados quantitativos, as cartas de alforria trazem informações qualitativas que revelam pormenores daquela realidade. Como muito bem observou Paulo Moreira, comentando as potencialidades que as manumissões têm, "a pretensa uniformidade dos agrupamentos obscurece uma realidade histórica caracterizada pela pluralidade de experiências sociais individuais" (MOREIRA, 2003, p. 147) ${ }^{48}$.

Portanto, o esforço aqui empreendido, embora uma ou outra análise qualitativa tenha sido realizada, abarca parte da complexidade do processo que redundava em liberdade. Para o contexto que serviu de palco para as indagações por nós levantadas, por exemplo, questões como a produção pecuária e a fronteira foram influíram diretamente na produção 
de liberdades ${ }^{49}$. Contudo, por vezes, para entendê-las, apenas um olhar mais apurado, 0 cruzamento de fontes e, de novo, uma apreciação qualitativa dão conta dos pormenores desse processo. Este fenômeno, não custa repetir, foi um dos mais corriqueiros do Brasil escravista, e sem o qual se tornaria quase que impossível a compreensão daquela realidade/ sociedade.

\section{Referências}

ALMEIDA, K. L. N. Alforrias em Rio de Contas - Bahia (século XIX). Salvador: EDUFBA, 2006.

ARAÚJO, Thiago L. de. Escravidão, fronteira e liberdade: políticas de domínio, trabalho e luta em um contexto produtivo agropecuário (Vila da Cruz Alta, Província do Rio Grande de São Pedro, 1834 - 1884). 2008. Dissertação (Mestrado em História) - Universidade Federal do Rio Grande do Sul, Porto Alegre, 2008.

BARTH, F. Process and form in social life. Londres: Routlegde \& Kegan Paul, 1981.

BERTIN, E. Alforrias na São Paulo do século XIX: liberdade e dominação. São Paulo: USP, 2004.

CHALHOUB, S. Visões da Liberdade: uma história das últimas décadas da escravidão na corte. Rio de Janeiro: Companhia das Letras, 1990.

Precariedade estrutural: o problema da liberdade no Brasil escravista (século XIX). História Social, Campinas, n.19, pp. 33-62, 2ำ semestre de 2010.

CUNHA, M. C. da. Antropologia do Brasil: mito, história, etnicidade. São Paulo: Brasiliense, 1986.

DAVIS, D. B. O problema da escravidão na cultura ocidental, Rio de Janeiro: Civilização Brasileira, 2001.

DOUGLAS, M. Matriliny and Pawnship in Central Africa. Journal of the International African Institute, Cambridge, n.4, v.34, pp. 301-313, oct. of 1964.

FERRAZ, Lizandra M. Entradas para a Liberdade: formas e frequência da alforria em Campinas, século XIX. 2010. Dissertação (Mestrado em História) - Universidade Estadual de Campinas, Campinas, 2010.

FERREIRA, A. B. de H. Novo Aurélio Século XXI: o dicionário da língua portuguesa. Rio de Janeiro: 1999.

FERREIRA, R. Cross-Cultural Exchange in the Atlantic World: Angola and Brazil during the Era of the Slave Trade. Cambridge: Cambridge University Press, 2012. 
FLORENTINO, M. e GÓES, J. R. A paz nas senzalas: famílias escravas e tráfico atlântico, Rio de Janeiro, c.1790 - c.1850. Rio de Janeiro: Civilização Brasileira, 1997.

FLORENTINO, M. Sobre minas, crioulos e a liberdade costumeira no Rio de Janeiro, 17891881. FORENTINO, M. (org.). Tráfico, cativeiro e liberdade: Rio de Janeiro, séculos XVIIXIX. Rio de Janeiro: Civilização Brasileira, 2005.

Sobre manumissões e fugas no Rio de Janeiro imperial. ECHEVERRI, A. M. A.; FLORENTINO, M., et al. (orgs.). Impérios Ibéricos em Comarcas Americanas: estudos regionais de história colonial brasileira e neogranadina. Rio de Janeiro: PPGHUFRJ/7Letras, 2010.

Freire, Jonis. Escravidão e família escrava na Zona da Mata mineira oitocentista. 2009. Dissertação (Mestrado em História) - Programa de Pós-Graduação em História, Universidade Estadual de Campinas, Campinas, 2009.

GONÇALVES, A. L. Às margens da liberdade: Estudo sobre a prática de alforrias em Minas colonial e provincial. Belo Horizonte: Fino Traço, 2011.

GRINBERG, K. Escravidão e Relações Diplomáticas Brasil e Uruguai, século XIX. In: V ENCONTRO ESCRAVIDÃO E LIBERDADE NO BRASIL MERIDIONAL, 2009. Curitiba. Anais do IV Encontro Escravidão e Liberdade no Brasil Meridional. Curitiba: UFPR, 2009.

GUEDES, R. A amizade e a alforria: um trânsito entre a escravidão e a liberdade (Porto Feliz, SP, século XIX). Afro-Ásia, Salvador, n.35, pp. 83-141, jan./jun., 2007.

Egressos do cativeiro: trabalho, família, aliança e mobilidade social (Porto Feliz, São Paulo, c.1798-c.1850). Rio de Janeiro: Mauad X/Faperj, 2008.

LACERDA, A. H. D. Demografia escrava e alforrias em Juiz de Fora (Minas Gerais, século XIX). Revista Científica da Faminas, Muriaé, n.2, v.1, pp. 39-62, 2005.

LARA, S. H.Campos da Violência: escravos e senhores na Capitania do Rio de Janeiro. Rio de Janeiro: Paz e Terra, 1988.

Fragmentos setecentistas: escravidão, cultura e poder na América Portuguesa. São Paulo: Companhia das Letras, 2007.

LOVEJOY, P. E. e RICHARDSON, D. The business of slaving: pawnship in western Africa, c. 1600-1810. In: LOVEJOY, P. e FALOLA, T. Pawnship, slavery and colonialismo in Africa. Trenton: Africa World Press, 2003, pp.27-54.

LOVEJOY, P. E. e FALOLA, T. Pawnship in Historical Perspective. In: LOVEJOY, P. E. e FALOLA, T. Pawnship, slavery and colonialismo in Africa. Trenton: Africa World Press, 2003, pp.1-26.

MATHEUS, M. S. Fronteiras da Liberdade: escravidão, hierarquia social e alforria no extremo sul do Império do Brasil. São Leopoldo: Oikos/Unisinos, 2012.

Frank Tannenbaum e os direitos dos escravos: religião e escravidão na América inglesa. Afro-Ásia, Salvador, n.51, pp. 213-250, 2015. 
A produção da diferença: escravidão e desigualdade social ao sul do Império brasileiro (Bagé, c.1820-1870). Rio de Janeiro: PPGH/UFRJ, 2016.

MATTOS, H. Das Cores do Silêncio: os significados da liberdade no sudeste escravista Brasil, século XIX. Rio de Janeiro: Arquivo Nacional, 1995.

Laços de família e direitos no final da escravidão. In: ALENCASTRO, L. F. de. História da vida privada no Brasil - Império: a corte e a modernidade nacional. Companhia das Letras: São Paulo, 1997, pp. 337-383.

MILLER, J. Way of death: merchant capitalism and the Angolan Slave Trade, 1730-1830. Madison: University of Wisconsin Press, 1978.

The Significance of Drought, Disease and Famine in the Agriculturally Marginal Zones of West-Central Africa. Journal of African History, Cambridge, n.1, v.23, pp. 17-61, 1982.

MOREIRA, P. R. S, Os cativos e os homens de bem: experiências negras no espaço urbano. Porto Alegre - 1858-1888. Porto Alegre: EST, 2003.

PEDRO, Alessandra. Liberdade sob condição: alforrias e política de domínio senhorial em Campinas, 1855-1871. 2009. Dissertação (Mestrado em História) - Universidade Estadual de Campinas, Campinas, 2009.

REIS, J. J. Domingos Sodré - um sacerdote africano: escravidão, liberdade e candomblé na Bahia do século XIX. São Paulo: Companhia das Letras, 2008.

RUBERT, A. História da Igreja no Rio Grande do Sul. Vol. 2. Porto Alegre: EDIPUCRS, 1998.

SCHERER, Jovani de S.Experiências de busca da liberdade: alforria e comunidade africana em Rio Grande, séc. XIX. 2008. Dissertação (Mestrado em História) - Universidade do Vale do Rio dos Sinos, São Leopoldo, 2008.

SLENES, R. W. Na senzala, uma flor: esperanças e recordações na formação da família escrava no sudeste do Brasil, século XIX. Rio de Janeiro: Nova Fronteira, 1999.

A Great Arch Descending: Manumission Rates, Subaltern Social Mobility and Enslaved, Freeborn and Freed Black Identities in Southeastern Brazil, 1971-1888. In GLEDSON, John; SCHELL, Patience (org.).New Approaches to Resistance in Brazil and Mexico. Durham, Duke University Press, 2012, pp.100-118.

SOARES, M. de C. Mina, Angola e Guiné: Nomes d'África no Rio de Janeiro Setecentista. Tempo, Rio de Janeiro, n.6, v.3, pp.1-13, 1998.

SOARES, M. A remissão do cativeiro: a dádiva da alforria e o governo dos escravos nos Campos dos Goitacases, 1750-1830. Rio de Janeiro: Apicuri, 2009.

TANNENBAUM, F. Slave and Citizen: the negro in the Américas. New York: A. A. Knopf, 1947. 
TEIXEIRA, H. M. O papel da liberdade: alforrias em Mariana no século XIX (1840-1888). In: SEMINÁRIO SOBRE A ECONOMIA MINEIRA, 15, 2012. Anais do Seminário sobre economia mineira. Diamantina: 2012, pp. 1-25.

THOMPSON FLORES, M. F. da C. Manejando soberanias: o espaço de fronteira como elemento na estratégia de fuga e liberdade (relativa) de escravos no Brasil meridional na segunda metade do século XIX. In: V ENCONTRO ESCRAVIDÃO E LIBERDADE NO BRASIL MERIDIONAL, 2011. Anais do V Encontro Escravidão e Liberdade no Brasil Meridional. Porto Alegre: UFRGS, 2011.

XAVIER, R. C. da S. A Conquista da Liberdade: libertos em Campinas na segunda metade do século XIX. Campinas: CMU/UNICAMP, 1996.

ZERO, A. H. Escravidão e liberdade: as alforrias em Campinas no século XIX (1830-1888). Campinas: PPGH/Unicamp, 2009.

\section{Notas}

1 "Liberdade que o senhor dá ao escravo. Do árabe alhorria" (FLORENTINO, 2005, p. 361); "Liberdade concedida ao escravo. Do árabe al-hurrya" (FERREIRA, 1999, p. 95).

2 Arquivo do Museu Dom Diogo de Souza. Fundo Jornais. 'O Bageense', 15 de janeiro e 26 de fevereiro de 1865.

3 Será possivel observar que não iremos gastar tinta nem espaço com a apresentação (de maneira pormenorizada) das características socioeconômicas e demográficas da localidade. Para tanto, o leitor poderá acessar o trabalho referido nessa nota - ou, quando preciso, o mesmo será referenciado ao longo do texto.

4 Ideia que, no geral, foi aceita por outros historiadores, em maior ou menor grau (DAVIS,2001, pp. 48 e 194). Estas e todas as demais traduções, do inglês para o português, são do autor.

5 Já em relação à América inglesa e aos Estados Unidos (doravante EUA), Frank Tannenbaum destaca que, no direito inglês, não havia leis específicas para os escravos, dado o estranhamento dessa instituição para essa nação (TANNENBAUM, 1947, p. 65 e nota 152). Sobre a questão, ver (MATHEUS, 2015).

6 Ao contrário deste corpo de leis que previam a alforria, na América inglesa foram colocados obstáculos para que os cativos chegassem à liberdade de diversas formas: em Demerara (atual Guiana), só se podia alforriar com a autorização do governador; em algumas ilhas do Caribe inglês, criaram-se impostos que deveriam ser pagos pelos senhores que desejassem libertar seus cativos; em Maryland, no ano de 1663, inclusive as mulheres livres que casassem com escravos deveriam servir ao senhor deste, sendo seus filhos escravos, e em 1717 interditou-se o casamento entre brancos e negros ou mulatos, sob pena de estes retornarem à escravidão; na Virgínia e na Carolina do Norte, um liberto que não saísse do estado em cerca de 12 meses poderia ser reescravizado; na Flórida, um negro ou um mulato poderia ser escravizado por divida; em estados como Alabama, Mississipi e Maryland, proibiu-se passar alforrias; no início do século XIX, em Barbados, aumentou-se o imposto sobre a manumissão de mulheres, no sentido de evitar a proliferação de pessoas de cor livres; na Carolina do Norte, legislou-se na década de 1830 que o escravo alforriado tinha 90 dias para deixar o estado (TANNENBAUM, 1947, pp. 52-62 e 65-71). Para uma interessante análise, a partir do inscrito nas diferentes Ordenações ibéricas sobre a alforria, ver (PEDRO, 2009, pp.105-110; e GONÇALVES, 2011, cap.1)

7 Com demonstrou Roquinaldo Ferreira, a instituição da pawnship era muito importante na África Central (FERREIRA, 2012, cap.2 e 3).

8 Paul Lovejoy e David Richardson relatam que, por volta de 1780, na região do porto de Calabar, mercadores ingleses utilizavam as palavras "pawn, pown, paun or prown" para distinguir a instituição da escravidão. Da mesma forma, em várias diferentes localidades africanas, ao longo da costa atlântica, utilizavam-se diferentes termos para a pawnship ("awowa in Akan, awubame in Ewe, awoba in Ga, iwofa in Yoruba, iyoha in Edo (Benin) and abrofa in Akwamu [...] and ubion in Efik/ Ibibio, igba ibe in Igbo, pagi in ljaw and gbanu in Fon"). Contudo, os autores complementam afirmando que, sem dúvida, alguns pawn "individualmente, terminaram como escravos" (LOVEJOYe RICHARDSON, 2003, pp. 30-32). 
9 Mary Douglas descreve a pawnship como um "sistema de transferência de direitos sobre determinadas pessoas que servia como compensação por infrações e liquidação de dividas, que eu chamo de pawnship", em que o direito sobre o trabalho poderia ser transmitido de maneira hereditária através da matriarcalidade (DOUGLAS, 1964, pp. 302-3).

10 Conforme Joseph Miller, muitos dos escravos embarcados em Luanda e Benguela eram produto de crises de fome, com as pessoas entrando, ou oferecendo parentes para tanto, voluntariamente na servidão (MILLER, 1982, p. 28).

11 Sobre os esforços da coroa portuguesa para que seus "vassalos", em territórios de Benguela e Angola sob administração portuguesa, não fossem escravizados e traficados para o Brasil como escravos ver (FERREIRA, 2012, cap. 2 e 3). Para a nomeação de Gervásio como cura de Bagé, ver (RUBERT,1998, p.81). O padre Gervásio Carneiro, após sair de Bagé em 1836, foi cura em Alegrete, onde ficou até 1842, ano em que foi produzido seu testamento. Nele, Gervásio alforria alguns escravos, dentre eles João Benguela, Antônio Congo, Maria Benguela, Joaquim Benguela e Domingas Benguela, todos da região onde Gervásio trabalhou quando esteve na África. Arquivo Público do Rio Grande do Sul (doravante APERS). Registro de Testamento. Alegrete, Provedoria. Gervásio Antônio Pereira, 1842.

12 Ver também (XAVIER, 1996).

13 Ou as diferentes ações e escolhas (ou processos) que geram padrões diversos (ou "modelos generativos") de produção da liberdade (BARTH, 1981, pp.32-34). Agradeço ao colega Luís A. Farinatti a sugestão para tal reflexão/relação.

14 Sabemos disso, pois o escrivão em não poucas vezes anotou esse pormenor. Por exemplo, na alforria da parda Silvéria, foi ressalvado que "copiei e conferi e achei conforme ao próprio original, entregando-a a "parda" Silvéria, que me pediu que a lançasse em nota", caso semelhante às manumissões dos "negros" Maria, João e Antônio, das "pardas" Maria Rita e Delfina, da "preta africana" Joana, dentre outros. APERS. Livro Notarial de Registros Diversos (doravante LNRD). Bagé, livro 1, pp. 1v, 2, 3, 5 e 5v, e livro 5, pp. 133 e 149.

15 Sobre a questão, ver também (ARAÚJO, 2008)

16 Desde o início da década de 1860, jornais em Bagé noticiavam sobre a Guerra de Secessão nos Estados Unidos: Arquivo do Museu Dom Diogo de Souza. Fundo Jornais. 'Aurora de Bagé', 03 de outubro de 1862.

17 Publicada em 2 de julho de 1856, "decretava que todos os escravos residentes em paises estrangeiros, ou vindos do exterior, que entrassem no território do Império deveriam ser colocados em liberdade não podendo serem entregues aos seus antigos senhores"(THOMPSON FLORES, 2011, p.17). Sobre o princípio de "solo livre", ver (GRINBERG, 2009).

18 Arquivo Histórico do Rio Grande do Sul. Delegacia de Polícia. Alegrete. Maço 1. Correspondência Expedida, 1856. Ao lado das perguntas (ao que parece em lápis), há a resposta para as três questões: para a primeira e segunda perguntas a resposta é "não"; para a última questão, a resposta é "sim".

19 APERS. LNTN. Bagé, livro 2, p. 119. Outras três alforrias foram produzidas em 1852, mas registradas entre 1859 e 1863 , as quais exigiam que $\mathrm{o}$ liberto condicional pagasse parte de sua liberdade com serviços no Estado Oriental. APERS. LNRD. Bagé, livro 3, pp. 54 e 89v e livro 4, p. 48. "Estado Oriental" era a denominação do atual Uruguai. Não iremos adentrar na questão de que tipo de liberdade esses libertos condicionais desfrutavam; todavia, como bem pontuou Sidney Chalhoub há alguns anos, "urge tornar agenda de pesquisa as consequências desses diversos tipos de alforria [condicionais] na experiência posterior da liberdade". O autor destaca tal necessidade, especialmente em razão da "dificuldade em determinar a condição dos filhos nascidos a mulheres escravas que haviam recebido liberdade condicional" (CHALHOUB, 2010, pp.43-44). Para um estudo que focou na concepção senhorial da concessão de alforrias, particularmente condicionais, mas a partir dos testamentos, ver (PEDRO, 2009).

$20 \mathrm{Em}$ três dos nove registros que trazem a ocupação do liberto, que foi identificado como "campeiro": APERS. LNTN. Bagé, livro 1, p. 95v e livro 2, p. 158v; LNRD. Bagé, livro 1b, p. 9, livro 3, pp. 9, 28, 32v, 54 e 89v e livro 5, pp. 11 e 18.

21 Sobre a noção de "grupos de procedência", ver (SOARES, 1998).

22 Maria Vinhol estabeleceu como condição para a liberdade da pequena Luíza "estar em minha companhia enquanto eu for viva, não podendo arredar-se salvo quando casar com pessoa que para isso tenha meu consentimento, e for indispensável tal separação". APERS. LNTN. Bagé, livro 1, p. 46; LNRD, Bagé, livro 1b, p. 35v e livro 5, p. 67.

23 A alforria de Joaquina foi registrada em agosto de 1859. APERS. LNRD. Bagé, livro 3, p. 48v. José Cacório (por vezes Cacósio na documentação), natural da São Paulo, foi um dos tantos libertos que alcançou significativa projeção social na localidade. A título de ilustração, em 1863 foi registrado o óbito do escravo José. Nele, foi indicado que, "nos subúrbios desta cidade de Bagé faleceu José, sem sacramentos, de uma úlcera carcinomatosa, de idade de 80 anos, africano, solteiro e escravo de José Cacório, preto liberto". ADB. Registros de Óbitos da Igreja de Bagé. Livro 1, p. 132v. A naturalidade de José está em um batismo de seu filho: RBIB. Livro 2, p. 49.

24 APERS. LNTN. Bagé, livro 2, p. 141; LNRD. Bagé, livro 4, p. 37. Arquivo da Diocese de Bagé (doravante ADB). Registros de Batismo da Igreja de Bagé (doravante RBIB). Livro 6b p. 41. Esses dois casos são belos exemplos dos mencionados encontros sociais, referidos anteriormente, que ajudam a explicar parte da quantidade enorme de filhos naturais de escravas. 
25 APERS. LNRD. Bagé, livro 3, p. 2 v e livro 5, p. 59. Onofre, cuja alforria abordamos no parágrafo anterior, Inácia e Abel estão entre aqueles 78 batizados como libertos. ADB. RBIB. Livro 5b, p. 71, e Livro 7b, p. 16.

26 APERS. LNRD. Bagé, livro 4, p. 35. ADB. RBIB. Livro 3, pp. 79v e 96v.

27 APERS. Processo-crime, Bagé, I Vara do Cível e Crime, no 3627, 1866. Outra "africana mina", Maria Isabel, também depõe, chamando Joana (que por vezes aparece pertencendo a Sipião Antunes Maciel) de "sua patrícia". Aliás, perguntada se conhecia as testemunhas que depunham contra ela, Maria Francisca do Rosário afirmou que "conhece as Minas há muito tempo e as outras há pouco". A impressionante trajetória de Maria Francisca do Rosário - especialmente sua ascensão social e sua rede de relações - é analisada com mais calma em (MATHEUS, 2016, cap.7).

28 APERS. LNTN. Bagé, livro 2, p. 181v. ADB. RBIB. Livro 3, pp. 41 e 135v. Arquivo do Museu Dom Diogo de Souza. 'Lista de Qualificação de Votantes, 1876-1878', p. 179. Dionísio José Leal compareceu mais vezes como "apresentante" (representante) de uma carta de liberdade em cartório. Por exemplo, na manumissão de Bárbara, que pagou 350 mil réis a seu senhor José Soares Leal, o escrivão assim anotou: "me reporto em mãos do portador Dionísio José Leal". APERS. LNRD. Bagé, livro 1, p. 47v. Sobre a participação de Dionísio como membro da Irmandade do Rosário, ver Arquivo Histórico do Rio Grande do Sul. Assunto Religiosos. Bagé. Maço 14. Irmandade do Rosário de Bagé, 1860. Agradeço a Ênio Grigio, que gentilmente cedeu as imagens dessa documentação.

29 APERS. LNTN. Livro 2, p. 169. A relação entre Bernabé e Felizarda deveria ser antiga, pois no assento de casamento de ambos consta que os pais de Bernabé, Mafalda Fagundes e o liberto Paulo, haviam sido "escravos de João Batista de Meirelles". ADB. Registros de Casamentos da Igreja de Bagé. Livro 3, p. 89.

30 Conforme João José Reis, a conquista da liberdade através alforria era uma fórmula tradicional "de emancipação individual e negociada - ao mesmo tempo que estratégia de controle senhorial". Para o autor, "a alforria era um expediente fundamental da política de controle paternalista. [...] Muitos escravos acreditavam que bons serviços e lealdade pudessem redundar em alforrias, sobretudo na hora em que os senhores, preparando-se para uma boa morte, escreviam seus testamentos" buscando "pagar seus pecados com esse tipo de caridade" (REIS, 2008, pp. 83 e 223).

31 Para maiores detalhes, ver (MATHEUS, 2016, cap.4).

32 Dois exemplos de estudos que abordaram as caracteristicas dos senhores que alforriaram são (GUEDES, 2008, cap. 4; e PEDRO, 2009, cap.1).

33 APERS. Registro de Inventário. Dona Ana Helena Correia da Silva de Borba. Comarca de Bagé. Vara de Família e Sucessão, no 416, 1879; APERS. Registro de Inventário. Nicolau Antônio Pereira. Comarca de Bagé. I Vara Cível e Crime, no 80, 1874. ADB. RBIB. No inventário da finada esposa de Nicola Antônio, Maria Teixeira Brasil, de 1852, foram arrolados 14 escravos: APERS. Registro de Inventário. Dona Maria Teixeira Brasil. Comarca de Caçapava. I Vara da Família, no 87, 1852. 34 É importante salientar também que há uma leve diferença nas faixas de plantel utilizadas: Roberto Guedes trabalhou com pequenos (até 10 escravos), médios (de 11 a 20) e grandes plantéis (mais de 20): (GUEDES, 2008, p. 192). Para os números apresentados para a estrutura de posse a partir dos batismos e inventários, ver (MATHEUS, 2016, cap.4).

35 A autora classifica escravarias com até 20 cativos como "pequenas", e de 21 a 40 como "médias". Para outros estudos que encontraram resultados próximos aos de Roberto Guedes e de Lizandra Ferraz, ver (SOARES, 2009, pp. 91-92; e FREIRE, 2009, pp. 319-322). Na faixa entre 1 e 20 escravos, os números observados por Jonis Freire, para Juiz de Fora, são ainda mais significativos.

36 ADB. RBIB. Livro 1, pp. 30 e 36, Livro 3, pp. 79v, 87v, 128v e 133v e Livro 4b, pp. 11v, 29v, 53, 53v, 87, 116v, 146v, 177v, 186v. APERS. LNTN. Bagé, livro 2, p. 57v; APERS. LNRD. Bagé, livro 6, p. 47v.

37 APERS. Registro de Inventário. José Antônio Pacheco. Comarca de Bagé. Vara da Família e Sucessão, no $254,1868$. ADB. RBIB. Livro 4b, p. 108. APERS. LNTN. Bagé, livro 2, p.277.

38 APERS. LNRD. Bagé, livro 1b, p. 35v, livro 3, p. 98 v e livro 4b, p. 10v. APERS. Registro de Inventário. Luís Vinhol. Comarca de Bagé. I Vara Cível e Crime, № 29, 1867. ADB. RBIB. Livro 4b, p. 59.

39 APERS. Registro de Inventário. Emerenciana Joaquina dos Santos. Comarca de Caçapava. Provedoria, no 08, 1859; Registro de Inventário. Francisca Joaquina Xavier. Comarca de Caçapava. Provedoria, no 06, 1857; LNRD. Bagé, livro 2 , pp. 52, 53, 53v e 64v.

40 APERS. Registro de Inventário. Feliciana Joaquina Jorge. Comarca de Caçapava. Provedoria, n 03, 1853; LNTN. Bagé, livro, p. 2, p. 5 v.

41 APERS. LNTN. Bagé, livro 1, pp.33, 33v e 34; LNRD. Bagé, livro 3, pp. 28, 32v e 71v e livro 5, pp. 48, 77, 122 v, $148 v$ e 149. Os Martins tiveram um dos únicos ministros, representando a província do RS, do Estado imperial - o irmão de Domingos, Gaspar Silveira Martins. Já entre os Netto destaca-se Antônio de Souza Netto, filho de José, um dos principais líderes dos rebeldes farroupilhas, e Brigadeiro Honorário do Império na Guerra do Paraguai. Para o monte-mor, ver (MATHEUS, 2016, p. 379).

42 APERS. LNTN. Bagé, livro 2, p. 205v. 
43 APERS. LNRD. Bagé, livro 1, p.1v. A partir da estrutura de posse realizada conforme os batismos, $41 \%$ das alforrias de pequenos senhores foram condicionais, sendo impressionantes $63 \%$ delas de senhoras e/ou de casais. Contudo, de acordo com a envergadura dos senhores apreendidas dos batismos, $31,5 \%$ das manumissões foram gratuitas, e $27,5 \%$ tiveram alguma forma de pagamento envolvido.

44 APERS. LNRD. Bagé, livro 4, p.5.

45 ADB. RBIB. Livro 3, pp. 83, 123 e 143v, Livro 4a, p. 145v, Livro 4b, p.2v e Livro 5b, pp. 61 e 71.

46 APERS. LNRD. Bagé, livro 5, p. 68v. (grifo nosso)

47 APERS. Registro de Testamento. Augusto José Nogueira, no 271, maço 6, estante 46, 1874.

48 Sobre tal questão, ver também: (PEDRO, 2009, pp.103-105).

49 Para uma análise mais refinada do processo de produção de liberdades na realidade aqui estudada, ver: (MATHEUS, 2012, cap.3 e 5, e MATHEUS, 2016, cap.6).

Marcelo Santos MATHEUS. Doutor em História Social pela Universidade Federal do Rio de Janeiro. Professor do Instituto Federal do Rio Grande do Sul. RS 239, Km 68, n. 3505, Rolante, 95690-000 RS, Brasil, Pesquisa financiada pela Capes. 